\title{
Invited review: Roles of dietary n-3 fatty acids in performance, milk fat composition, and reproductive and immune systems in dairy cattle
}

\author{
U. Moallem ${ }^{1}$ \\ Department of Ruminant Science, Institute of Animal Sciences, the Volcani Center, 68 HaMaccabim Road, Rishon LeZion 7505101, Israel
}

\begin{abstract}
Mammals can synthesize all of the fatty acids (FA) necessary for proper health and functioning with the exception of FA in the n-3 (omega-3) and n-6 (omega-6) families of polyunsaturated fatty acids (PUFA), which should be supplied in the diet. The PUFA are the predominant type of lipid in dairy cattle diets; however, common feedstuffs are rich in n-6 FA, whereas the supply of n-3 FA in the intensive dairy industry is mainly limited to flaxseed and fish oils. The n-3 FA are involved in many biological systems and processes, and therefore their dietary supplementation is of special interest in dairy cattle. Furthermore, because milk, milk products, and meat are among the most important and widely used components in traditional and modern human diets, enrichment of these food products with n-3 FA is of special importance. The purpose of this review is to provide a comprehensive description of different aspects and outcomes involved in dietary n-3 FA supplementation in dairy cattle. I provide an inclusive review of the effects of n-3 FA on milk and milk solids and the FA profile in milk fat upon feeding a variety of flaxseed products or fish oil. Selective uptake of n-3 FA has been demonstrated in the ovary compartments, as well as in bull sperm and in the unborn calf through the placenta. Incorporation of these unique FA into the reproductive system influences many processes and exerts some positive effects on fertility. In addition, beneficial effects of feeding n-3 FA on the reproductive system of females and males can be achieved with supplementation of $\alpha$-linolenic acid from flaxseed or from eicosapentaenoic and docosahexaenoic acids from fish oil. This work provides a broad perspective and demonstrates the importance and potential of n-3 FA dietary supplementation in dairy cattle on the animal itself, as well as its secondary effects, which are associated with human nutrition and health.
\end{abstract}

Received March 20, 2018.

Accepted June 11, 2018.

${ }^{1}$ Corresponding author: uzim@volcani.agri.gov.il
Key words: n-3 fatty acid, flaxseed oil, fish oil, milk fat composition, reproductive system

\section{INTRODUCTION}

Fatty acids (FA) are involved in several biological systems and processes, including the immune system (Prescott and Calder, 2004; Sordillo, 2016), blood coagulation and vascular resistance, enzyme activities, cell proliferation and differentiation, and receptor expression (Clandinin et al., 1991). They are the main components of cell membranes and their composition influences cell function. The n-3 (omega-3) FA are potent participants in the aforementioned functions (Deckelbaum et al., 2006). Their distinct characteristics of long chain length and the presence of a double bond on the third carbon atom from the methyl end of the molecule endow these FA with unique biological capabilities.

Furthermore, unbranched chain PUFA with 20 and 22 carbons, and especially long-chain n-3 FA, play an important physiological role during pregnancy, both in the pregnant dam and in the unborn calf, as they are critical for the development of the central nervous system (Koletzko et al., 2007; Innis, 2008) and the reproductive system (Stoffel et al., 2008).

Research in our laboratory has demonstrated the beneficial effects of n-3 FA supplementation on the reproductive system in dairy cows (Zachut et al., 2010b, 2011; Moallem et al., 2013) and bulls (Moallem et al., 2015), as confirmed in other reports. Feeding n-3 FA attenuated endometrial $\mathrm{PGF}_{2 \alpha}$ (Mattos et al., 2004), and cows fed rolled flaxseed exhibited decreased pregnancy loss rates and larger ovulatory follicles (Ambrose et al., 2006). All of these aspects of dietary n-3 FA in reproduction will be discussed in detail in this review.

The increase intake of n-3 FA, especially eicosapentaenoic acid (EPA; C20:5n-3) and docosahexaenoic acid (DHA; C22:6n-3), is associated with reduced susceptibility to cardiovascular diseases in humans (Breslow, 2006), as well as reduced susceptibility to hypertension and arthritis (Simopoulos, 2002). In westernized societies, consumption of n- 6 PUFA is increasing, and the $n$ 
-6:n-3 FA ratio has increased from 2.4 in primitive human diets to 12.0 in modern human diets (Simopoulos, 2002). Diets with lower n-6:n-3 ratios are considered healthier for humans.

Thus, it appears that the importance of dietary n-3 FA in cattle does not apply only to the animal per se; as milk, milk products, and meat are among the main contributors to human nutrition, enrichment of these products with n-3 FA is also of special importance.

Several reviews (Petit, 2010; Leroy et al., 2014) and meta-analyses (Leduc et al., 2017) have been published recently on the effects of PUFA in ruminants; however, those papers reviewed specific topics relating to the effects of long-chain FA supplementation. In an excellent review, Palmquist (2009) summarized aspects related to n-3 FA supplementation on metabolism, health, and animal product foods, but that review included all domestic animals and was more focused on the effects on human nutrition. The objectives of the current review are to provide a broad perspective on all aspects of dietary n-3 FA supplementation from flaxseed and fish oil in cattle, including its effects on production (yields of milk and milk solids, enrichment of milk with n-3 FA) and physiology (the reproductive system in cows and bulls, the unborn calves), and a short evaluation of the effects on the immune system and health.

\section{LONG-CHAIN FATTY ACIDS}

Based on their chemical structure, FA can be differentiated into 3 main groups: (1) SFA, no double bonds, (2) MUFA, only 1 double bond present, and (3) PUFA, at least 2 double bonds present. Of particular interest to the present review are the long-chain unbranched UFA in ruminant nutrition. Long-chain PUFA can be divided into 3 main families, depending upon the site of the first double bond from the methyl side: n-3, n- 6 , and n-9. All n-3 and n-6 FA are PUFA, whereas most of the n-9 FA are MUFA (such as oleic acid, C18:1n-9; OA). Both n-3 and n-6 FA are considered essential FA because they cannot be synthesized de novo by mammals. However, although the original 18-carbon molecule of each class can undergo de novo elongation and further desaturation (Mattos et al., 2000), the position of the first double bond remains the same.

\section{FATTY ACIDS IN RUMINANT NUTRITION}

Traditional dairy cow diets typically have a low ether extract concentration (around $2.5-3.5 \%$ of dietary DM). The most common sources of oilseeds fed to dairy cows are soybean, corn, and cottonseed, but others include canola, rapeseed, flaxseed, safflower, and sunflower. In addition, several plant and animal byproducts that contain fat or oil, such as distillers grains and fish meal, are common in ruminant diets. Fat supplements are regarded as energy sources, and the increasing energy requirements of the high-yielding dairy cow have led to a steady rise in the use of fat supplements in ruminant nutrition. However, increasing the proportion of dietary fat may be detrimental to bacterial growth and fiber digestibility, along with other negative effects (Jenkins, 1993). These adverse effects of fat supplementation can be reduced by the use of rumen-protected fats, which pass through the rumen partly intact with the fat released for digestion in the small intestine. Several approaches are used to protect fat against digestion in the rumen; for example, calcium salts of FA, encapsulation, and extrusion. It should also noted that, as reported in a meta-analysis study published by Weld and Armentano (2017), except for the medium-chain SFA supplementation, all other dietary fat had no effect or even increased the total-tract digestibility of NDF.

The predominant type of lipid in the dairy cow diet is the PUFA. These are cereal- and oilseed-derived triglycerides and forage-derived glycolipids. Dietary lipids can be in the form of free FA or complexed FA, such as triglycerides. The common oilseeds in the ruminant diet contain 70 to $90 \%$ UFA. The main FA in cereals and oilseeds are 18-carbon FA, and fish products are rich in long-chain PUFA such as EPA and DHA (Chilliard et al., 2007).

As mentioned, there are 2 main families of PUFA, n-3 and $\mathrm{n}-6$, and the n-6:n-3 ratio is considered an indicator of PUFA value. The proportions of the main long-chain FA, total SFA, MUFA, PUFA, and n- 6 and n- 3 contents in the oils of most common feedstuffs in ruminant rations are presented in Table 1. It should be noted that oil FA profiles might differ between publications because of differences in the raw material and analytical methods. Furthermore, the range of specific FA in the same oil from different sources, fields, or even seasons might be very wide. Within species of plants, genetic variants, due to either selection or genetic modification, may also influence the FA composition of oils derived from these plants. Similarly, the FA composition of fish oil depends on the species of fish and the location and time of year of their capture (Khan et al., 2012). As can be seen in Table 1, FA composition varies among oils but, in general, the available feedstuff in dairy cow rations includes a high proportion of UFA and a low proportion of SFA. Palm oil is commonly consumed as calcium salts of FA in ruminant nutrition, and is rich in n-9 FA (C18:1n-9). Soybean oil and sunflower oil are very rich in n-6 FA and, except for flaxseed, soybean, and fish oils, all other common feedstuffs contain negligible amounts of n-3 FA. Ruminant rations include a mixture of oils from a variety of feedstuffs, and the 
Table 1. Approximate proportion (g/100 g of total fatty acids) of long-chain fatty acids in oils of most common feedstuffs in ruminant rations ${ }^{1}$

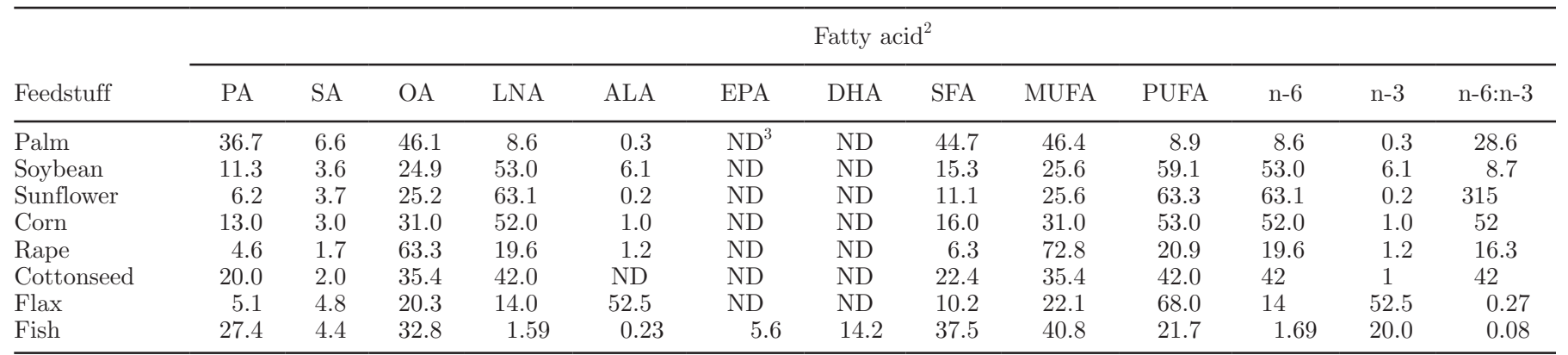

${ }^{1}$ Data were obtained from Khan et al. (2012), Omidi et al. (2015), Orsavova et al. (2015), and Suksombat et al. (2016).

${ }^{2} \mathrm{PA}=$ palmitic acid $(\mathrm{C} 16: 0) ; \mathrm{SA}=$ stearic acid (C18:0); OA = oleic acid (C18:1n-9); LNA = linoleic acid (C18:2n-6); ALA = $\alpha$-linolenic acid $(\mathrm{C} 18: 3 \mathrm{n}-3) ; \mathrm{EPA}=$ eicosapentaenoic acid (C20:5n-3); DHA = docosahexaenoic acid (C22:6n-3); n-6 = total n-6 fatty acids; n-3 = total n-3 fatty acids.

${ }^{3}$ Not detected.

combination of these oils determines the final n-6:n-3 ratio in the diet.

Unsaturated FA that reach the rumen are, to a large extent, converted to SFA by biohydrogenation activity of the microflora (Jenkins, 1993). The aforementioned processes (e.g., as calcium salts of FA, encapsulation, extrusion) that have been developed to avoid the adverse effects of natural oils on fiber digestibility also partially protect UFA from ruminal biohydrogenation. The ruminal biohydrogenation level is varied, and depends on the form and composition of supplemented $\mathrm{FA}$, rumen $\mathrm{pH}$, and diet composition; for example, biohydrogenation of calcium salts has been investigated extensively, with in vivo reports varying from no protection to about $40 \%$ of the PUFA being protected (Fievez, et al., 2007). A variety of processes has been used in many studies to partly protect dietary n-3 from ruminal biohydrogenation.

\section{EFFECTS OF n-3 FA SUPPLEMENTATION ON PERFORMANCE IN DAIRY COWS}

Two main sources exist for n-3 FA inclusion in ruminant diets: flaxseed, which is a botanical source and rich in $\alpha$-linolenic acid (ALA; C18:3n-3), and fish oil, an animal source that is rich in EPA and DHA. Fish oil and fish meal have been examined in ruminant rations for 2 reasons: fish oil as a source of the long-chain n-3 FA EPA and DHA, considering their unique function, and fish meal as a source of rumen-undegraded protein. However, the botanical n-3 source flaxseed is preferable in ruminant nutrition because fish oil has been found to suppress feed intake in many studies when fed at $>1 \%$ of dietary DM (Donovan et al., 2000; AbuGhazaleh et al., 2002; Whitlock et al., 2002); indeed, most studies have been conducted with flaxseed. Flaxseed contains a relatively high proportion of protein and energy -20 to $22 \% \mathrm{CP}$ and 35 to $40 \%$ ether extract on a DM basis (Petit, 2002, 2003).

\section{Effects on DMI}

Although fat supplements differ markedly in their effects on DMI, all of them - even those considered to be rumen protected - tend to reduce DMI (Allen, 2000; Rabiee et al., 2012). For example, Schauff and Clark (1992) demonstrated a linear decrease in DMI with supplementation of increasing amounts of calcium salts of long-chain FA to dairy cows. Several factors are involved in the detrimental effects of supplemental fat on feed intake in ruminants: physical and chemical characteristics of the fat supplement (e.g., oils, extruded and whole oilseeds, prilled FA, calcium salts of FA), chain length, degree of saturation, level of the supplemental fat in the diet, and stage of lactation (Allen, 2000; Rabiee et al., 2012). Several reports have demonstrated a decrease in intake with abomasal infusion of UFA (Drackley et al., 1992; Bremmer et al., 1998), or when cows were fed increasing amounts of UFA at the expense of SFA (Harvatine and Allen, 2006). Many other studies, using flaxseed in a variety of forms, have determined effects on intake. Heat treatment can be used to partly protect oilseeds from ruminal degradation and biohydrogenation by denaturing the protein matrix surrounding the fat droplets (Kennelly, 1996); therefore, most of the studies in dairy cows have been conducted using the extruded flaxseed (EF) form. Supplementation of $\mathrm{EF}$ to the diet at a rate of $9.2 \%$ of dietary DM during early lactation increased DMI compared with control cows (Zachut et al., 2010a). This positive effect of EF on intake was not found by Gonthier et al. (2005), who fed cows EF at $12.6 \%$ of the diet, or Neveu et al. (2013), who fed cows EF at a rate of 9\% (DM basis). Ferlay et al. (2013) fed increased amounts of 
EF (from 5 to $15 \%$ of DM) and did not observe any effects on DMI. In contrast, Martin et al. (2008) found a decline in DMI when feeding EF at $5.7 \%$ of dietary DM. Several other studies have examined the effect of whole flaxseed and found no effect on intake (Petit, 2002; Petit et al., 2004). In another study, encapsulated flaxseed oil was given to dairy cows at a rate of $2.9 \%$ of dietary DM with no effect on feed intake (Moallem et al., 2013). These inconsistencies may be attributed to many factors, such as the supplement's form, odor, and acceptability; level and duration of supplementation; stage of lactation; and dietary composition. Furthermore, it is plausible to assume that the varied effects of feeding flaxseed on intake are not directly related to the presence n-3 FA in the supplement per se, but to the general effect of fats and oils, especially long-chain UFA, on intake in ruminants.

Because fish oil, the source of the longer n-3 FA, has been found to suppress intake in dairy cows in many studies, there are fewer studies using this source of n-3 FA. Pirondini et al. (2015) fed cows fish oil at a rate of $0.8 \%$ of dietary DM and did not find any negative effect on intake. As described in several reports, the negative effects of feeding fish oil on intake largely depend on the amount fed. Donovan et al. (2000) reported a similar DMI when fish oil was fed at a rate of $1 \%$ of dietary DM, whereas higher concentrations of fish oil in the diet decreased DMI. Similarly, Keady et al. (2000) found a negative effect when fish oil was supplemented at a rate of $>300 \mathrm{~g} / \mathrm{d}$ per cow, and Doreau and Chilliard (1997) reported a lower DMI when fish oil was administered to lactating dairy cows at $400 \mathrm{~mL} / \mathrm{d}$, but not at $200 \mathrm{~mL} / \mathrm{d}$. Fish oil has a unique odor that may reduce intake when incorporated into the diet at high rates.

\section{Effects on Milk Yield and Content of Milk Solids}

Milk Yield. Many studies have examined the effects of different forms of flaxseed, including whole flaxseed, $\mathrm{EF}$, or even encapsulated flaxseed oil on milk yield. Supplementation of EF at a rate of $4 \%$ (DM basis) increased milk yield by $2.7 \%$ (Moallem, 2009); this was not found by Gonthier et al. (2005), who fed dairy cows $\mathrm{EF}$ at a rate of $12.7 \%$ of DM. In another study, feeding transition dairy cows (from calving until 100 DIM) with 9.2\% EF (DM basis) increased milk yield by $6.4 \%$ (Zachut et al., 2010a). Neveu et al. (2013) fed dairy cows EF at $9 \%$ of their diet (DM basis) and did not find any effect on milk yield, as also reported by Martin et al. (2008) in cows fed EF at a rate of $5.7 \%$ of DM. In Hurtaud et al. (2010), increasing amounts of EF linearly increased milk yield, in contrast to Ferlay et al. (2013), who fed increasing amounts of EF (from 5 to $15 \%$ of DM) but did not observe any effect on milk yield among the groups.

Several studies have examined the effect of whole flaxseed on dairy cow performance. Petit et al. (2004) fed dairy cows $9.7 \%$ whole flaxseed and found higher milk yields as compared with controls or cows fed $9.6 \%$ whole sunflower. In another study, Petit et al. (2007) supplemented dairy cows with whole flaxseed at $11 \%$ of their diet during the transition period (from $6 \mathrm{wk}$ prepartum until 28 DIM), and did not observe any effect on milk yield. Similarly, Kennelly (1996), Petit et al. (2005), and Mustafa et al. (2003) did not observe any effects of feeding whole flaxseed on milk yield. Suksombat et al. (2016) supplemented cows with pure flaxseed oil, and did not find any effects on milk yield relative to palm oil. Among other reasons, the effects on milk yield might be mediated by feed intake and, as we have seen, the effects of feeding flaxseed in different forms are inconsistent, which might explain, in part, the variations in the effect on milk yield.

Fish oil provides the long-chain n-3 FA EPA and DHA. Cant et al. (1997) fed cows $2 \%$ fish oil and did not observe any effect on milk yield, in agreement with AbuGhazaleh et al. (2002), who fed cows with fish oil at up to $2 \%$ of dietary DM. Moallem et al. (2013) fed cows encapsulated fish oil at $2.9 \%$ of DM and observed no effect on milk yield compared with cows fed encapsulated SFA or flaxseed oil at the same rate. Donovan et al. (2000) fed cows increasing amounts of fish oil and found an increase in milk yield for cows fed $1 \%$ fish oil, followed by a linear decrease with addition of fish oil up to 3\% of DM. Pirondini et al. (2015) found a tendency toward higher milk yield when cows were fed fish oil at $0.8 \%$ of their diet. In most of these studies, supplementation of fish oil did not affect milk yield, and a high rate of fish oil in the diet decreased feed intake, which may partly explain the adverse effect on yield as in Donovan et al. (2000).

Milk Fat. A reduction in milk fat percentage was found by Moallem (2009) in cows fed 4\% EF in their diet or in transition cows fed EF at $9.2 \%$ of DM (Zachut et al., 2010b). This is consistent with Martin et al. (2008), who fed cows EF at a rate of $5.7 \%$ of DM. Neveu et al. (2013) fed dairy cows EF at 9\% of the diet (DM basis) and found a tendency toward reduced milk fat content. In Hurtaud et al. (2010), increasing amounts of EF linearly decreased milk fat content. A similar trend was demonstrated by Ferlay et al. (2013), who fed cows with increasing amounts of EF (from 5 to $15 \%$ of DM) and found a decrease in milk fat percentage with increasing amounts of $\mathrm{EF}$ in the diet. However, this negative effect on milk fat content was not found by Gonthier et al. (2005), who fed dairy cows EF at a rate of $12.7 \%$ of DM. 
Other studies have examined the effects of other forms of flaxseed. Mustafa et al. (2003) observed lower milk fat content in cows fed unheated flaxseed. However, other studies that involved feeding whole flaxseed (Petit et al., 2004, 2005, 2007; Akraim et al., 2007) did not find a lower fat percentage in the milk. Moallem et al. (2013) supplemented transition cows with encapsulated flaxseed oil and found a reduction in milk fat percentage compared with feeding with SFA. It seems that extruded flaxseed products are not completely protected against biohydrogenation of PUFA by the microflora to intermediate isomers that are known to depress milk fat (Baumgard et al., 2001) or are associated with milk fat depression (Piperova et al., 2004). These isomers have been associated with depression of FA synthesis in the mammary gland, mainly affecting short-chain FA up to C16. Moreover, in an in vitro study, Lee and Jenkins (2011) demonstrated the formation of several conjugated linoleic acid isomers from ALA in a continuous culture fermentor with mixed rumen microbes. The effect of feeding flaxseed on fat content in milk is highly correlated with the form of protection, and therefore, to the rate of exposure of UFA to biohydrogenation in the rumen.

Moallem et al. (2013) fed cows encapsulated fish oil at $2.9 \%$ of DM and the milk fat content was lower than in cows fed SFA. This is consistent with Donovan et al. (2000), who fed cows with increasing amounts of fish oil and found a quadratic decrease in milk fat percentage. Cant et al. (1997) fed cows $2 \%$ fish oil and found a decrease in milk fat with no effect on milk yield. This trend of decreasing milk fat in cows was also found by Spain et al. (1995) and Blauwiekel et al. (1990), who supplemented cows with fish meal. Pirondini et al. (2015) did not find any effect on fat percentage from feeding fish oil at $0.8 \%$ of dietary DM, similar to AbuGhazaleh et al. (2002), who fed cows fish oil at $2 \%$ of their diet.

Thus, in most of the studies in which flaxseed or fish products were supplemented to dairy cows, the fat percentage in milk was reduced, most likely due to the formation of intermediate trans FA isomers by biohydrogenation in the rumen that suppress milk fat synthesis in the mammary gland.

Milk Protein. Many reports have demonstrated a reduction in milk protein content when fat is supplemented in a variety of forms. Wu and Huber (1994) reported that milk protein content decreases regardless of the type of fat fed, whereas Rabiee et al. (2012) reported that the largest negative effect on protein percentage was elicited by calcium salts of FA. No effects on milk protein percentage were found by Moallem (2009), who fed cows $4 \% \mathrm{EF}$ in their diet, or by Zachut et al. (2010a), who fed transition cows EF at
$9.2 \%$ of DM, findings that are consistent with those of Martin et al. (2008) in cows fed EF at a rate of 5.7\% of DM, as well as of Gonthier et al. (2005). Other studies that involved feeding whole flaxseed (Petit et al., 2004, 2007; Akraim et al., 2007) also did not find any effect on milk protein percentage. In addition, Mustafa et al. (2003) did not observe any effect on milk protein percentage upon feeding whole or micronized flaxseed, and Ferlay et al. (2013) fed increasing amounts of EF (from 5 to $15 \%$ of DM) and did not observe any effects on protein percentage in milk. However, Petit et al. (2005) observed a lower milk protein percentage when feeding whole flaxseed compared with a control diet, and, in Hurtaud et al. (2010), increasing amounts of EF resulted in a linear decrease in milk protein content.

The use of low rumen-degradable proteins such as fish meal is considered to enhance cow performance. Many studies have been conducted with fish meal rather than fish oil with the aim of increasing milk and milk solids performance. Fish meal contains, on average, $>20 \%$ fat, providing long chain n-3 FA (Khan et al., 2012); fish oil is readily released from fish meal (Spain et al., 1995). Supplementing fish meal at a rate of $\sim 9 \%$ of the diet did not affect milk protein but decreased milk fat percentage (Windschitl, 1991). In other studies in which cows were fed fish oil (Cant et al., 1997; Pirondini et al., 2015) or encapsulated fish oil (Moallem et al., 2013), a reduction in milk protein percentage was observed, whereas no effect of feeding fish oil on milk protein percentage was observed by AbuGhazaleh et al. (2002) or Donovan et al. (2000).

Milk Lactose. No effect of feeding encapsulated flaxseed oil on lactose percentage in milk was observed by Moallem et al. (2013), or by Zachut et al. (2010b), Martin et al. (2008), Moallem (2009), or Gonthier et al. (2005), who fed cows EF. Moreover, in other studies in which whole flaxseed was supplemented, no effects on lactose were found (Gonthier et al., 2005; Martin et al., 2008). Similarly, fish oil supplementation did not affect lactose percentage in milk (Cant et al., 1997; Donovan et al., 2000; AbuGhazaleh et al., 2002; Pirondini et al., 2015).

\section{Effects on FA Profile in Milk Fat}

As expected, supplementation of n-3 FA greatly influences the FA profile in milk fat, as observed in many studies. The effects of dietary supplementation of n-3 FA on the profile of the main categories of FA in milk fat FA are presented in Table 2 . The proportion of palmitic acid (PA) was reduced in cows supplemented with EF (Zachut et al., 2010b), whole flaxseed (Petit et al., 2004, 2005, 2007), and EF (Moallem, 2009). This trend of reduced PA content in milk fat was also ob- 
Table 2. Effects of supplementation of a variety of flaxseed products to dairy cows on the content of several families of fatty acids in milk fat

\begin{tabular}{|c|c|c|c|c|c|c|c|c|c|}
\hline Reference & $\begin{array}{l}\text { Flaxseed } \\
\text { form }\end{array}$ & $\begin{array}{l}\text { Rate }^{1} \\
\%\end{array}$ & $\begin{array}{l}\text { ALA intake, }{ }^{2} \\
\text { g/d per cow }\end{array}$ & $\begin{array}{c}\mathrm{SFA}_{\%}^{3} \\
\%\end{array}$ & $\underset{\%}{\text { MUFA, }^{3}}$ & $\underset{\%}{\text { PUFA, }}{ }^{3}$ & $\begin{array}{c}\mathrm{n}-6,{ }^{3} \\
\%\end{array}$ & $\begin{array}{c}\mathrm{n}-3,^{3} \\
\%\end{array}$ & $n-6: n-3$ \\
\hline Petit et al. (2004) & Whole & 9.7 & 529.2 & -3.2 & +3.5 & -0.3 & 0.77 & +0.53 & -3.7 \\
\hline Petit et al. (2005) & Whole & 11.8 & 670.0 & -9.9 & +9.9 & +0.33 & -0.25 & +0.4 & -1.6 \\
\hline Gonthier et al. (2005) & Micronized & 12.7 & 369.6 & -10.8 & +0.86 & +2.2 & +0.9 & +0.9 & -2.77 \\
\hline Gonthier et al. (2005) & Extruded & 12.7 & 389.6 & -15.5 & +13.3 & +2.3 & +1.1 & +0.3 & -0.57 \\
\hline Fuentes et al. (2008) & Extruded & 5.5 & 255.0 & -4.0 & +2.96 & +1.05 & -0.11 & +0.67 & -4.9 \\
\hline Chilliard et al. (2009) & Extruded & 5 & 441.7 & -15.2 & +12.47 & +2.52 & +1.55 & +0.48 & -0.05 \\
\hline Chilliard et al. (2009) & Oil & 5 & 578.0 & -26.6 & +22.34 & +4.06 & +4.48 & -0.23 & +8.95 \\
\hline Petit and Côrtes (2010) & Whole & 7.2 & 463.8 & -5.7 & +0.55 & +0.31 & -0.34 & +0.48 & -2.03 \\
\hline Petit and Côrtes (2010) & Ground & 7.2 & 387.1 & -6.0 & +0.54 & +0.7 & -0.23 & +0.78 & -2.39 \\
\hline Zachut et al. (2010b) & Extruded & 3.8 & 242.2 & +0.72 & -1.79 & +1.07 & -0.39 & +1.57 & -12.7 \\
\hline Zachut et al. (2010a) & Extruded & 9.2 & 376.2 & -6.81 & +5.32 & +1.48 & +0.17 & +1.29 & -6.01 \\
\hline Oeffner et al. (2013) & Extruded & 8.3 & 280.0 & -10.3 & +8.3 & +1.95 & +1.44 & +0.53 & -0.06 \\
\hline Oeffner et al. (2013) & Extruded & 11.8 & 420.0 & -12.4 & +9.1 & +3.23 & +2.54 & +0.70 & +0.29 \\
\hline
\end{tabular}

${ }^{1}$ Percent of dietary DM of the supplemented n-3 product.

${ }^{2}$ The $\alpha$-linolenic acid (ALA) intake was reported or calculated from the cited publications.

${ }^{3}$ Changes in percentage units (g/100 g of total fatty acids) compared with the control of the sum of SFA, MUFA, PUFA, n- 6 fatty acids, or n-3 fatty acids, respectively.

served by Gonthier et al. (2005), Akraim et al. (2007), and Mustafa et al. (2003) in cows fed a variety of flaxseed forms. Moreover, increased amounts of EF linearly decreased the PA proportion in milk fat (Hurtaud et al., 2010; Zachut et al., 2010a).

The proportion of stearic acid (SA) in milk fat increased in cows fed encapsulated flaxseed oil (Zachut et al., 2010b) and in those fed whole flaxseed (Petit et al., 2005, 2007). Similarly, the proportion of SA in milk fat was higher in cows supplemented with EF than in controls (Moallem, 2009). In addition, the SA content in milk increased in cows supplemented with a variety of flaxseed forms (Mustafa et al., 2003; Akraim et al., 2007); and in those fed whole flaxseed (Petit et al., 2004). Furthermore, increasing amounts of supplemented EF linearly increased the proportion of SA in milk fat (Hurtaud et al., 2010).

The proportion of OA in milk fat did not change in transition cows fed EF (Zachut et al., 2010a), in cows fed encapsulated flaxseed oil (Zachut et al., 2010b), or in those fed whole flaxseed (Petit et al., 2004). The OA content in milk fat increased in cows fed whole flaxseed (Petit et al., 2005, 2007), a variety of flaxseed forms (Mustafa et al., 2003; Gonthier et al., 2005; Akraim et al., 2007), and EF (Moallem, 2009). Akraim et al. (2007) further analyzed the FA and found that C18:1 trans and cis isomers increased with feeding of a variety of flaxseed forms. The increased amounts of EF in
Hurtaud et al. (2010) linearly increased all types of OA isomers in milk fat.

The linoleic acid (LNA) profile did not change in cows fed encapsulated flaxseed oil (Zachut et al., 2010b) or in transition cows fed EF (Zachut et al., 2010a). In Petit et al. (2004), C18:2n-6 trans did not increase but C18:2n-6 cis did change upon feeding with whole flaxseed. Petit et al. (2005) observed increased contents of C18:2n-6 trans-trans, but no differences in the other C18:2 isomers with supplementation of whole flaxseed. In Akraim et al. (2007), the cis-9,trans-11 C18:2 and trans-11,cis-15 C18:2 isomers increased with feeding of a variety of flaxseed forms, but cis-9, cis-12 C18:2 decreased. Mustafa et al. (2003) also observed an increase in C18:2 cis isomers upon feeding a variety of flaxseed forms. Gonthier et al. (2005) found an increase in LNA with a variety of flaxseed forms. Increasing amounts of EF in Hurtaud et al. (2010) tended to increase the proportion of LNA isomers in milk fat.

The enrichment of milk fat with OA and LNA upon feeding n-3 FA is of special importance because the intermediate isomers associated with milk fat depression are derived from these FA.

\section{Enrichment of Milk Fat with n-3 FA}

$A L A$ (C18:3n-3). Milk ALA content was enhanced in all studies in which cows were supplemented with 
all forms of flaxseed. The proportion of ALA in milk fat increased 6.6-fold (from 0.25 in the control to 1.65 $\mathrm{g} / 100 \mathrm{~g}$ of total FA in the EF-fed cows) with provision of $242.2 \mathrm{~g}$ of C18:3n-3 from EF (Zachut et al., 2010b). In Zachut et al. (2010a), transition cows were supplemented with encapsulated flaxseed oil, providing 376.2 $\mathrm{g} / \mathrm{d}$ of ALA, and the proportion of ALA in milk fat was 5.1-fold higher than in control cows (from 0.29 in the control to $1.47 \mathrm{~g} / 100 \mathrm{~g}$ of total FA in the EF-fed cows). In Moallem et al. (2013), cows were supplemented with encapsulated flaxseed oil providing $131.0 \mathrm{~g} / \mathrm{d}$ of ALA, and the proportion of ALA in milk fat was 3 times higher than in cows fed SFA (from 0.31 in the SFA to $0.93 \mathrm{~g} / 100 \mathrm{~g}$ of total FA in the cows fed encapsulated flaxseed oil). In Gonthier et al. (2005), the proportion of ALA in the milk fat of cows fed raw or micronized flaxseed was 3.25 times higher, and 1.8 times higher in cows fed EF than in control cows $(1.3,1.3,0.7$, and $0.4 \mathrm{~g} / 100 \mathrm{~g}$ of total FA in the micronized flaxseed, raw flaxseed, EF, and control cows, respectively). In Petit et al. (2004), cows were fed whole flaxseed at 9.7\% of dietary DM, and ALA in the milk fat was 1.8-fold higher than in control cows (1.1 and $0.6 \mathrm{~g} / 100 \mathrm{~g}$ of total FA, respectively). In Akraim et al. (2007), cows were fed raw flaxseed or EF at a rate of $\sim 16.5 \%$ of dietary $\mathrm{DM}$, and the ALA proportion was 3.5 and 4.4 times higher than in control cows, respectively $(0.95,1.20$, and $0.27 \mathrm{~g} / 100 \mathrm{~g}$ of total FA in the raw flaxseed, EF, and control cows, respectively). Mustafa et al. (2003) fed cows micronized or whole flaxseed at $7 \%$ of dietary $\mathrm{DM}$, and the ALA proportion was 2.5 and 3 times higher, respectively, than in control cows $(1.0,1.2$, and $0.4 \mathrm{~g} / 100 \mathrm{~g}$ of total FA, respectively). In cows fed whole flaxseed at $11 \%$ of dietary DM, the proportion of ALA was 1.5-fold higher than in the control group (Petit et al., 2007). In Petit et al. (2005), cows were fed $\sim 11.8 \%$ whole flaxseed and the proportion of ALA was 1.9-fold higher than in the control cows. Soita et al. (2003) fed cows $1 \mathrm{~kg}$ of raw or micronized flaxseed and the proportion of ALA was 1.8-fold higher than in control cows. In Hurtaud et al. (2010), cows were fed increasing amounts of EF, providing 120 or $240 \mathrm{~g} / \mathrm{d}$ of ALA, and the proportion of ALA increased by 1.9 - and 2.9 -fold, respectively, compared with controls $(0.44,0.67$, and $0.23 \mathrm{~g} / 100 \mathrm{~g}$ of total FA, respectively). In Moallem (2009), ALA was 3.1-fold higher in cows fed EF at $4 \%$ of dietary DM than in controls $(0.93$ and $0.3 \mathrm{~g} / 100 \mathrm{~g}$ of total FA, respectively). In these studies, ALA in the milk fat increased 1.5- to 6.6-fold, depending mainly on dietary ALA amounts but also on other parameters, such as method of delivery. The highest enrichment of milk fat with ALA (content and yields) was reported by Moallem et al. (2012) in cows that were abomasally infused with $220 \mathrm{~mL}$ of flaxseed oil/d; the ALA proportion increased to 3.3, with an average yield of $50.6 \mathrm{~g} / \mathrm{d}$.

The transfer rate of ALA from the diet to milk fat averaged $5.9 \%$ in cows fed EF, providing $376.2 \mathrm{~g} / \mathrm{d}$ per cow of ALA (Zachut et al., 2010a), and only 2\% for cows fed a variety of flaxseed sources (Gonthier et al., 2005). In contrast, the apparent transfer efficiency for cows abomasally infused with 52 and $104 \mathrm{~g} / \mathrm{d}$ of ALA was 44.8 and $45.7 \%$, respectively (Moallem et al., 2012). Similarly, the apparent transfer efficiency of ALA in Côrtes et al. (2011) was 44.7 and $41.0 \%$ for cows infused with 256 and $521 \mathrm{~g} / \mathrm{d}$ of flaxseed oil, respectively. The extremely low apparent transfer efficiency for ALA supplied in the diet compared with infusion is almost certainly attributable to high rates of rumen biohydrogenation of ALA, reducing the supply that reaches the site of absorption in the small intestine and limiting the supply available to the mammary gland for incorporation into milk fat, as suggested by Gonthier et al. (2005).

EPA (C20:5n-3). In many studies with supplemented flaxseed products, the very long chain FA were not detected, probably because of analytical difficulties. The proportion of EPA was 2-fold higher in cows fed EF at $4 \%$ of dietary DM (Moallem, 2009). The proportion of EPA in the milk fat was not affected by provision of $242.2 \mathrm{~g}$ of $\mathrm{C} 18: 3 \mathrm{n}-3$ from EF to transition cows (Zachut et al., 2010b). In Zachut et al. (2010b), mid-lactation cows were supplemented with encapsulated flaxseed providing $376.2 \mathrm{~g} / \mathrm{d}$ of $\mathrm{C} 18: 3 \mathrm{n}-3$, and the proportion of EPA in the milk fat was 4.5 -fold higher than in controls. In Petit et al. (2005), the proportion of EPA was 1.5-fold higher in cows supplemented with whole flaxseed at $\sim 11.8 \%$ of DM.

Docosapentaenoic (C22:5n-3) and DHA Acids. The proportion of docosapentaenoic acid (DPAn-3) was 2.1-fold higher in cows fed EF at $4 \%$ of dietary DM (Moallem, 2009), and 3-fold higher with provision of $242.2 \mathrm{~g} / \mathrm{d}$ of ALA to transition cows from EF (Zachut et al., 2010a). In Zachut et al. (2010b), mid-lactation cows were supplemented with EF providing $376.2 \mathrm{~g} / \mathrm{d}$ of ALA, and the proportion of DPAn-3 in the milk fat was 3 -fold higher. To the best of my knowledge, DHA has not been detected in any of the experiments in which flaxseed products were supplemented.

\section{FATTY ACIDS IN HUMAN NUTRITION}

The effects of supplementation of a variety of flaxseed products on the proportions of SFA, MUFA, PUFA, n-3 and n- 6 FA and the n-6:n-3 ratio in milk fat are summarized in Table 2. In most of the reports, the proportion of SFA decreased while those of MUFA and 
PUFA increased with the feeding of flaxseed products. In addition, in all reports, the proportion of n-3 FA was enhanced and the n-6:n-3 ratio decreased.

In most of the studies reviewed here, milk fat was enriched with n-3 FA upon dietary supplementation of flaxseed products. The enrichment of milk fat with $\mathrm{n}-3 \mathrm{FA}$ ranged from 0.2 to $0.5 \mathrm{~g} / 100 \mathrm{~g}$ of total $\mathrm{FA}$ in control cows to 1.0 to $1.77 \mathrm{~g} / 100 \mathrm{~g}$ of total FA in the flaxseed-supplemented cows. In several publications, daily n-3 FA yields were reported and ranged from 2.7 to $8.3 \mathrm{~g} / \mathrm{d}$ in control cows to 5 to $29.1 \mathrm{~g} / \mathrm{d}$ in flaxseedsupplemented cows.

Milk and milk products are among the most important and widely used components in the modern human diet; in westernized societies, consumption of n-6 PUFA has increased, and the n-6:n-3 ratio has increased from 1:1 in primitive human diets to 10:1 in modern diets (Wathes et al., 2007). In addition, meat, which may also be enriched with n-3 FA (Elmore et al., 2005), is one of the major sources of FA in the human diet. Simopoulos (2002) suggested that the $\mathrm{n}-6: \mathrm{n}-3$ ratio in diets has changed from $\sim 1$ for evolving human beings to 15 to 16.7 in modern Western diets. She also suggested that a lower n-6:n-3 FA ratio is desirable for reducing the risk of many of the chronic diseases plaguing Western societies (Simopoulos, 2002). The estimated calories required for adult human is $\sim 2,200$ calories/d, and about $35 \%$ of total daily calories come from fat. If $50 \%$ of daily fat consumption is from dairy products, an adult human consumes $\sim 40 \mathrm{~g}$ of fat from dairy products. Enrichment of milk fat with $\sim 1.2 \mathrm{~g} / 100 \mathrm{~g}$ of total FA means that human intake of n-3 FA (mainly as ALA) would increase by about $0.5 \mathrm{~g} / \mathrm{d}$. Considering the recommended amounts of 1 to $1.5 \mathrm{~g} / \mathrm{d}$ of n-3 FA, about $30 \%$ of the daily consumption of n-3 FA would come from the enrichment of milk fat with these FA. In addition, as can be seen in Table 2 , a reduction in the $\mathrm{n}$ $-6: n-3$ ratio in milk fat with dietary supplementation of n-3 FA in dairy cows is accompanied by a reduction in SFA content and enhanced proportions of MUFA and PUFA, all of which are desirable in human nutrition.

\section{Effects of Fish Oil Supplementation on Milk Fat Composition}

Several studies have determined the effects of feeding fish meal or fish oil on milk fat composition. Cant et al. (1997) fed cows fish oil at 2\% of dietary DM and found an increase in the proportions of ALA, EPA, and DHA in the milk fat $(0.5,6.22$, and 2.28 percentage units, and additional yields of $0.3,3.1$, and $11 \mathrm{~g} / \mathrm{d}$, respectively). Donovan et al. (2000) fed cows with increasing amounts of fish oil in the diet and found a linear increase in EPA and in total n-3 FA $(0.17,0.27$, and
0.35 percentage units in cows fed fish oil at 1,2 , and $3 \%$ of diet DM, respectively); they also found a linear decrease in the proportion of SFA $(61.1,54.9,49.0$, and $48.2 \%$ in cows fed fish oil at $0,1,2$, and $3 \%$ of diet $\mathrm{DM}$, respectively) and a linear increase in that of UFA (27.6, 30.8, 35.8, and 37.0, respectively). AbuGhazaleh et al. (2002) fed cows fish oil at $2 \%$ of DM and found an increase of $0.31,0.19$, and 0.22 percentage units in ALA, EPA, and DHA, respectively; they also observed a decrease in SFA (from $69.5 \%$ in control to $63.1 \%$ in fish oil cows) and an increase in UFA (from $24.6 \%$ in control to $27.4 \%$ in fish oil cows) in the milk fat. In Pirondini et al. (2015), cows were fed fish oil at $0.8 \%$ of DM, and they reported an increase in EPA, DPA, and DHA, a decrease in SFA, and an increase in PUFA.

\section{Effects of Dietary n-3 on Plasma FA Profile}

The effects of dietary n-3 FA supplementation on plasma FA profile is of major importance, because it ensures the spread of dietary effects through the circulation to all tissues and organs, with the expected influences on function. The effect of feeding flaxseed on plasma FA composition has been determined in a few studies, and some of the available data are summarized in Table 3. In most of the studies, there was a decrease in n-6 FA and an increase in n-3 FA in the blood. In addition, the plasma n-6:n-3 ratio decreased in all reports; however, its range was relatively wide, from -3.7 (from 5.99 in the control to 2.26 in the EF-supplemented cows; Gonthier et al., 2005) to -40.7 (from 48.9 in the control to 8.2 in the EF-supplemented cows; Zachut et al., 2010a). In addition, in general, the SFA proportion decreased and MUFA and PUFA proportions increased in the plasma upon feeding flaxseed.

The plasma FA profile was determined in Moallem et al. (2013), in cows fed encapsulated fish oil or SFA at $2.9 \%$ of dietary DM. The proportion of EPA was 6.2 times higher in the fish oil group than the SFA group (1.43 and $0.23 \%$, respectively). The proportion of DPAn-3 was 2.7 times higher in cows supplemented with fish oil than in cows fed SFA (0.09 and 0.24\%, respectively), and the proportion of DHA was 11 times higher in cows fed fish oil than in their SFA-fed counterparts (0.04 and $0.43 \%$, respectively). In addition, the total proportion of n-3 FA in the plasma was higher in the fish oil group than in cows fed SFA, and the n-6:n-3 ratio in the plasma decreased from 19.1 in the SFA-fed cows to 7.31 in cows fed fish oil (Moallem et al., 2013).

\section{EFFECTS OF n-3 FA SUPPLEMENTATION ON THE REPRODUCTIVE SYSTEM}

The effects of n-3 FA supplementation on the dairy cow reproductive system have been investigated at a 
few levels: ovaries and uterus, embryo survival, in vitro fertilization (IVF), and behavioral estrus.

\section{Incorporation of n-3 FA into Ovarian Compartments}

Follicular Fluid. The incorporation of dietary FA into ovarian compartments has been documented in several reports. In Zachut et al. (2010a), transition cows were supplemented with EF at $9.2 \%$ of their diet and the composition of FA in the follicular fluid (FF) collected from estradiol $\left(\mathbf{E}_{2}\right)$-active follicles was determined. The proportion of ALA in the FF was more than 7 times higher in the EF-fed cows than in controls. The proportions of the longer n-3 FA (C20:4n-3 and EPA) were also higher in the FF of EF-fed cows, and the ratio of n-6:n-3 FA in the FF decreased from 45:1 in the controls to 4.9:1 in the EF-fed cows. In another study (Moallem et al., 2013), cows were supplemented with encapsulated SFA, flaxseed, or fish oil. The proportion of ALA in the FF of cows fed encapsulated flaxseed oil was 2.5 times higher than in control cows fed encapsulated SFA, whereas the total proportion of $\mathrm{n}-3 \mathrm{FA}$ in the cows fed encapsulated flaxseed oil was 2.2 times higher than in the SFA group. The n-6:n-3 ratio in the FF was higher in SFA- versus flaxseed-fed cows (17.4 and 7.6, respectively; Moallem et al., 2013).

Other studies have investigated the effects of dietary n-3 from fish oil on FA composition in FF. In a study conducted in ewes, supplementation of calcium salts of fish oil increased the proportion of DHA in FF from 0 (control) to $1.3 \%$ in the fish oil-supplemented ewes (Zeron et al., 2002). Childs et al. (2008) fed heifers increasing amounts of partially protected fish oil and found that the proportion of EPA, but not DHA, in the FF increased, whereas the n-6:n-3 ratio decreased markedly. In Moallem et al. (2013), cows were fed encapsulated fish oil and the proportion of EPA in the FF was 2.5 times higher than in control cows, whereas the proportion of DHA was 9.3 times higher.
In general, the FA profile in FF is very similar to that in plasma. This indicates relatively free passage of plasma FA into FF, which is a crucial condition for altering ovarian activity and the oocyte environment via absorption of blood FA exclusively from dietary supplementation, and in our case, long-chain FA.

Granulosa Cells. The effect of feeding EF on FA composition of granulosa cells has only been determined in a small number of studies. In Zachut et al. (2011), cows were fed EF at a rate of $9.2 \%$ of DM and the composition of the FA in granulosa cells obtained from $\mathrm{E}_{2}$-active follicles aspirated in vivo was determined. The proportion of ALA was 4.5 times higher and that of C20:4n-3 was 6 times higher in cows supplemented with EF compared with controls. The proportion of EPA was also higher in the EF-fed cows, and the proportions of DPAn-3 and DHA were numerically but not significantly higher in the EF-fed versus control cows (Zachut et al., 2011). The total n-3 FA content increased from $1.6 \%$ in the controls to $7.8 \%$ in the EF-fed cows, and the n-6:n-3 ratios were 29.0 and 5.2 , respectively. In another study (Zachut et al., 2010b), cows were fed encapsulated flaxseed oil or sunflower oil at $3.8 \%$ of dietary DM. The proportion of PA, which was predominant in granulosa cells, was lower in the EF-fed than control cows, and the proportion of LNA tended to be higher than in the control group. The proportion of $n-3$ FA in granulosa cells was 5.3-fold higher in cows fed encapsulated flaxseed oil than in control cows, and the proportion of PUFA was $48 \%$ higher than in the controls (Zachut et al., 2010b). The n-6:n-3 ratio in granulosa cells decreased from 29.4 in control cows to 9.3 in the cows fed encapsulated flaxseed oil. In Moallem et al. (2013), FA composition was determined in granulosa cells obtained from preovulatory follicles aspirated in vivo. The proportion of ALA in the granulosa cells was 2.5 times higher in cows fed encapsulated flaxseed oil than in those fed SFA. The total proportion of n-3 FA in granulosa cells was 1.78-fold higher and the n-6:n-3

Table 3. Effects of supplementation of a variety of flaxseed products to dairy cows on content of several families of fatty acids in the plasma

\begin{tabular}{|c|c|c|c|c|c|c|c|c|}
\hline Reference & $\begin{array}{l}\text { Flaxseed } \\
\text { form }\end{array}$ & $\begin{array}{c}\text { Rate, }{ }^{1} \\
\%\end{array}$ & $\begin{array}{c}\mathrm{SFA}^{2}{ }^{2} \\
\end{array}$ & $\begin{array}{c}\text { MUFA, }^{2} \\
\%\end{array}$ & $\underset{\%}{\mathrm{PUFA}^{2}{ }^{2}}$ & $\begin{array}{c}\mathrm{n}-6,{ }^{2} \\
\%\end{array}$ & $\begin{array}{c}\mathrm{n}-3,{ }^{2} \\
\%\end{array}$ & $n-6: n-3$ \\
\hline Petit et al. (2004) & Whole & 9.7 & +0.5 & +0.1 & -0.6 & -7.9 & +14.8 & -11.3 \\
\hline Gonthier et al. (2005) & Extruded & 12.6 & -2.4 & +7.4 & -5.1 & -12.5 & +6.8 & -3.7 \\
\hline Moallem (2009) & Extruded & 4.0 & +0.2 & +0.7 & -0.6 & -3.9 & +3.6 & -23.2 \\
\hline Fouladi-Nashta et al. (2009) & Extruded & 11.4 & -1.5 & +0.9 & +0.5 & -1.8 & +2.3 & -4.8 \\
\hline Moallem et al. (2013) & Encapsulated & 2.7 & -1.1 & -0.5 & +2.1 & -2.5 & +5.0 & -11.8 \\
\hline
\end{tabular}

${ }^{1}$ Percent of dietary DM of the supplemented n-3 product.

${ }^{2}$ Changes in percentage units (g/100 g of total fatty acids) compared with the control of the sum of SFA, MUFA, PUFA, n-6 fatty acids, or n-3 fatty acids, respectively. 
ratio was reduced from 16.1 in the SFA-fed cows to 7.55 in the cows fed encapsulated flaxseed oil (Moallem et al., 2013). Wonnacott et al. (2010) fed ewes a mixture of flaxseed and salmon oils and found an increase in ALA, C20:3n-3, EPA, and DHA in granulosa cells compared with ewes fed sunflower oil. The n-6:n-3 ratio decreased from 6.2 in the sunflower oil-fed ewes to 0.4 in the ewes fed a diet rich in n-3 FA (Wonnacott et al., 2010). In contrast, Fouladi-Nashta et al. (2009) fed cows EF at $11.4 \%$ of dietary DM and found changes in the plasma with no effect on granulosa cell FA composition. The development of primordial follicles into larger preantral and then ovulatory follicles takes 4 to 6 mo in cattle (Evans et al., 2012), and the subsequent growth from $0.3 \mathrm{~mm}$ to 3 to $5 \mathrm{~mm}$ in diameter takes more than 30 d (Mossa et al., 2012). Fouladi-Nashta et al. (2009) provided dietary FA supplementation for only a short time (25 d), which might explain the different responses obtained in these studies.

Other studies determined the effect of dietary fish oil on granulosa cell FA composition. In Zeron et al. (2002), ewes were fed rumen-protected fish oil, and the proportions of LNA, ALA, and DHA were enhanced in the cumulus cells of these ewes compared with controls. In Moallem et al. (2013), cows were fed encapsulated fish oil and the FA composition in granulosa cells obtained from preovulatory follicles was determined. The proportion of EPA and DPAn-3 in the granulosa cells was about twice that in cows fed SFA. The total n-6: $\mathrm{n}-3$ ratio in granulosa cells decreased from 16.1 in the SFA-fed cows to 10.9 in the fish oil-fed cows (Moallem et al., 2013).

Oocytes. The impact of dietary n-3 FA supplementation on oocyte FA composition has been determined in several reports. Cows were fed encapsulated flaxseed oil at $3.8 \%$ of dietary DM, and the FA composition of the cumulus-oocyte complex (COC) was determined (Zachut et al., 2010b); PA decreased from $47.9 \%$ in the control cows to $39.0 \%$ in cows supplemented with encapsulated flaxseed oil. In the supplemented cows, ALA amounted to $4.73 \%$, whereas it was not detected in the control group, and MUFA and PUFA increased by 3.4 percentage units in the supplemented group (Zachut et al., 2010b). Moallem et al. (2013) supplemented cows with encapsulated flaxseed oil at $2.7 \%$ of dietary DM and the proportion of ALA in COC was 3.2-fold that in their SFA-fed counterparts. No differences were observed in SFA, MUFA, or PUFA distribution between groups in that study. Wonnacott et al. (2010) fed ewes a mixture of flaxseed and salmon oils and found an increase in the proportions of ALA and EPA in oocytes obtained from those ewes compared with ewes fed sunflower oil rich in n-6 FA.
In Zeron et al. (2002), ewes fed rumen-protected fish oil showed enhanced proportions of ALA and EPA in their oocytes relative to control ewes. In Moallem et al. (2013), cows were fed encapsulated fish oil, and whereas DPAn-3 and DHA were not detected in the COC of control cows, their proportions in the COC of fish oil-fed cows were 1.11 and $1.17 \%$, respectively. The total proportion of n-3 FA tended to be higher in the COC of fish oil- versus SFA-fed cows, and the n- 6 : $\mathrm{n}-3$ ratio was 1.61 in the former compared with 3.04 in the latter (a nonsignificant difference; Moallem et al., 2013).

Rate of Incorporation of Dietary n-3 FA into Ovarian Compartments. The above findings indicate a very interesting selective uptake mechanism for specific long-chain FA into ovarian compartments. The profiles of several FA in the plasma, FF, granulosa cells, and oocytes in response to different dietary FA supplements are presented in Figure 1. These data are adapted from Moallem et al. (2013), in which cows were supplemented starting in the dry period through 100 DIM with encapsulated SFA, flaxseed oil, or fish oil. The contents of ALA in the blood, FF, granulosa cells, and oocytes are presented in Figure 1A: in contrast to the other FA, infiltration of ALA into all tissues was proportional to its enrichment in the blood. The content of EPA (Figure 1B), which originated from the fish oil, was high in oocytes, and although the blood of cows supplemented with fish oil was greatly enriched with this FA, it did not pass into the FF or subsequently into the other compartments. This means that infiltration of plasma EPA into FF is limited by a selective uptake mechanism. On the other hand, DPAn-3 (Figure 1C), which is synthesized de novo, accumulated in oocytes but not in the other compartments. The level of DHA (Figure 1D), which also originated from the fish oil, was high in the blood of cows supplemented with fish oil and, like DPAn-3, it accumulated mainly in the oocytes but also in FF. This selective uptake, which is known from other biological systems, suggests a unique role for each long-chain FA in different tissues or even different metabolism of each FA in each tissue. Alternatively, selective uptake may serve to protect the tissue from specific metabolites and molecules. This issue requires additional state-of-the-art research to elucidate the selective uptake mechanism, and its role, in the ovary.

\section{Effects on Other Reproductive Characteristics in Cows}

Several studies have investigated the effects of n-3 FA supplementation on a few other aspects of the reproductive system in cows. Mattos et al. (2002) fed cows 
with increasing amounts of menhaden fish meal, from 0 to $7.8 \%$ of the diet, which also contained fish oil $(0.28 \%$ of dietary DM). The concentration of the $\mathrm{PGF}_{2 \alpha}$ metabolite 13,14-dihydro-15-keto-PGF $\mathrm{PG}_{2 \alpha}$ after oxytocin injection was reduced in cows fed diets containing fish meal compared with those fed no fish meal. Petit et al. (2002) fed cows 4 diets: Megalac (Volac Ltd., Roston, Hertfordshire, United Kingdom), formaldehyde-treated whole linseed, a mixture of fish oil and formaldehydetreated whole linseed, or $500 \mathrm{~g} / \mathrm{d}$ of linseed oil infused into the duodenum. They did not find any effect on follicular dynamics, but the corpus luteum was larger in cows fed formaldehyde-treated whole linseed or the mixture of fish oil and formaldehyde-treated whole linseed (16.5 and $16.1 \mathrm{~mm}$, respectively, vs. $11.3 \mathrm{~mm}$ in cows fed Megalac and $11.1 \mathrm{~mm}$ in cows infused with linseed oil). The release of 13,14-dihydro-15-keto- $\mathrm{PGF}_{2 \alpha}$ in response to a standard oxytocin challenge in that study was lower for cows fed formaldehyde-treated whole lin- seed or infused with linseed oil (Petit et al., 2002). In Petit and Twagiramungu (2006), cows were fed whole flaxseed, Megalac, or micronized soybeans from calving to d 50 of pregnancy for pregnant cows or to $120 \mathrm{~d}$ postpartum for those not diagnosed as pregnant; cows that conceived within $120 \mathrm{~d}$ after calving showed no embryo mortality when fed whole flaxseed compared with $15.0 \%$ when fed Megalac or $8 \%$ in micronized soybeans, but there were no differences in conception or pregnancy rates among the treatments. In Ambrose et al. (2006), Holstein cows were supplemented with either rolled flaxseed or rolled sunflower seed $(\sim 750 \mathrm{~g}$ of oil/d) for $32 \mathrm{~d}$ after insemination; the ovulatory follicle was larger and the pregnancy losses were $9.8 \%$ in cows fed rolled flaxseed compared with $27.3 \%$ in those fed rolled sunflower. Petit and Benchaar (2007) found a higher conception rate at first AI in cows supplemented with whole flaxseed $(54.3 \%)$ than those fed with micronized soybeans (40\%). Zachut et al. (2011) supplemented

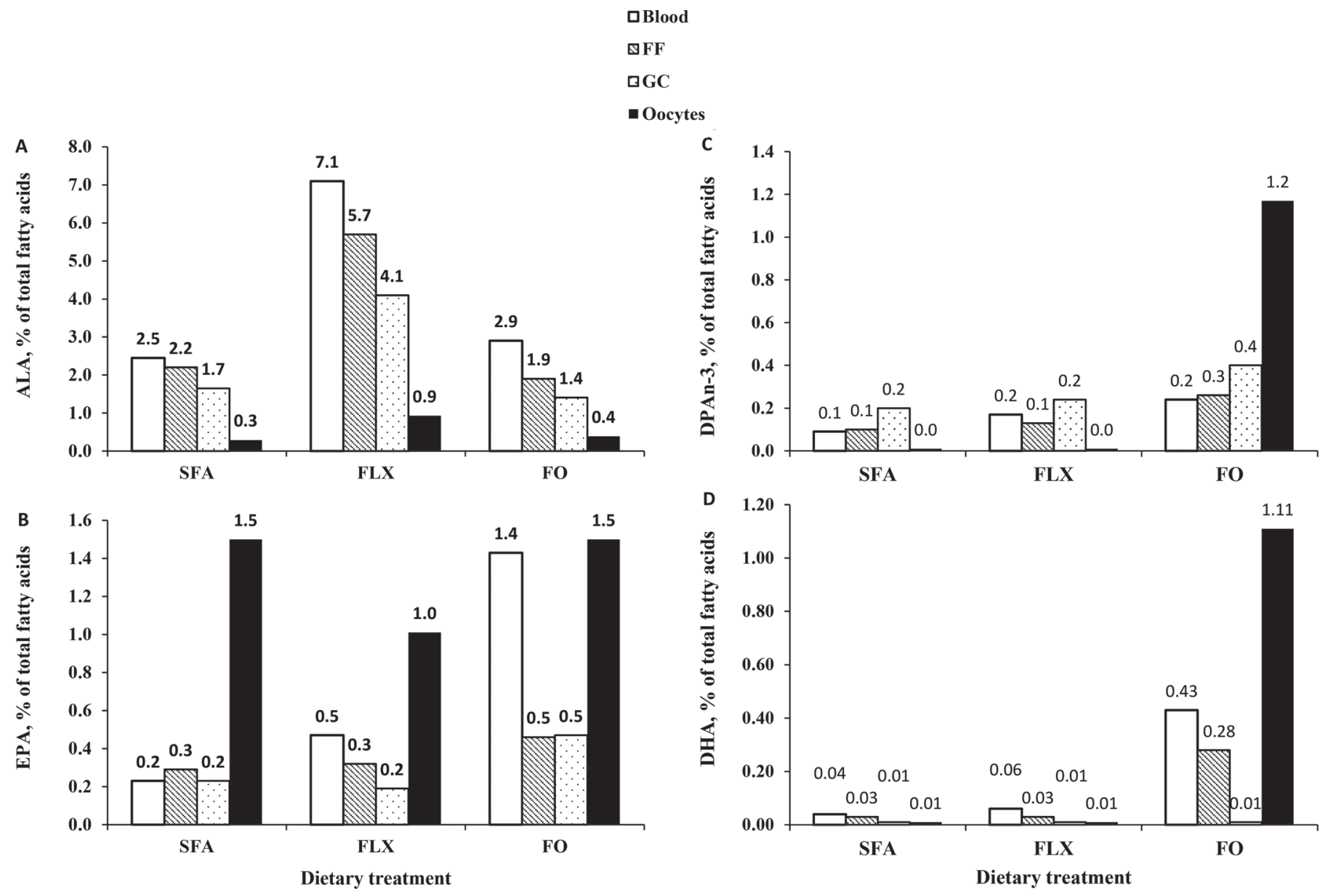

Figure 1. Proportion of (A) $\alpha$-linolenic acid (ALA), (B) eicosapentaenoic acid (EPA), (C) n-3 docosapentaenoic acid (DPAn-3), and (D) docosahexaenoic acid (DHA) in blood, follicular fluid (FF), granulosa cells (GC) and oocytes in cows supplemented with SFA, encapsulated flaxseed oil (FLX), or encapsulated fish oil (FO). 
cows from 3 wk prepartum through 100 DIM with $\mathrm{EF}$, and compared them to controls. The interval from $\mathrm{PGF}_{2 \alpha}$ injection to behavioral estrus peak or LH peak tended to be longer in the EF group, and the interval to $\mathrm{E}_{2}$ peak was longer in the $\mathrm{EF}$ than in the control cows. The durations of behavioral estrus $(18.6 \pm 0.8 \mathrm{~h}$ in the cows fed EF vs. $15.8 \pm 0.9 \mathrm{~h}$ in the control) and $\mathrm{E}_{2}$ surge were longer and the area under the $\mathrm{E}_{2}$ curve was greater in the EF cows.

Burke et al. (1997) fed menhaden fish meal at a rate of 2.7 to $3.2 \%$ of DM from -24 to 109 DIM to dairy cows in 2 herds and found a higher pregnancy rate in one of the herds (41.3 vs. $31.9 \%$ ). In a large-scale study conducted in our laboratory (data not yet published), 276 multiparous cows were supplemented prepartum with $\mathrm{EF}$ at $4 \%$ of $\mathrm{DM}$ and postpartum with $5 \%$ of the same supplement, and days from first AI to conception and open days tended to be fewer (17 and $18 \mathrm{~d}$, respectively) than in 240 cows fed a common diet. In another study, cows (primiparous and multiparous) were supplemented with an algae product containing $10 \%$ DHA (Sinedino et al., 2017). Feeding algae increased resumption of estrous at 58 DIM and pregnancy at first AI in primiparous cows, and increased pregnancy per $\mathrm{AI}$ in all $\mathrm{AI}$ in both primiparous and multiparous cows, which reduced days to pregnancy by $22 \mathrm{~d}$ compared with control cows (Sinedino et al., 2017).

\section{Follicular Dynamics and Estrous Cycle Pattern}

In Zachut et al. (2010b), cows were supplemented with encapsulated flaxseed or sunflower oil (rich in n- 6 FA) at $3.8 \%$ of DM. Ovaries were monitored by ultrasonography for follicular status, and the average numbers of 2- to 5 -mm follicles on d 5 and 9 of the cycle were higher in the cows fed encapsulated flaxseed oil than in those fed sunflower oil, whereas the average numbers of follicles $\geq 10 \mathrm{~mm}$ on $\mathrm{d} 5,9$, and 13 were higher in those fed sunflower oil than in those fed encapsulated flaxseed oil and controls. In contrast, Ponter et al. (2006) reported an increased number of small follicles in cows fed EF compared with those fed extruded soybeans (rich in C18:2n-6), with no difference in the number of medium-sized or large follicles. Similarly, the number of 3- to 7-mm-diameter follicles collected from cows supplemented with encapsulated flaxseed oil or fish oil during ovum pick-up procedures was higher than that from SFA-fed cows (Moallem et al., 2013). In another study, Heravi Moussavi et al. (2007) observed higher numbers of medium-sized (5- to $10-\mathrm{mm}$ ) follicles in cows that were fed $5 \%$ fish meal than in control cows or those fed smaller proportions (1.25 and $2.5 \%$ ) of fish meal, which is not in accord with Zachut et al. (2010b). However, Petit et al. (2004), who fed cows calcium salts of palm oil, whole flaxseed, whole sunflower seed $(6.2$ to $6.7 \%$ of $\mathrm{DM}$ ), or no supplementary fat, found no differences among treatments in follicular dynamics. Although the above results are conflicting, it seems that dietary n-3 FA influence the dynamics of follicular development in the ovary via an unknown mechanisms with inconsistent patterns.

\section{Preovulatory Follicle Characteristics}

In Zachut et al. (2010b), cows were supplemented with either encapsulated flaxseed oil or sunflower oil (rich in n-6 FA) at $3.8 \%$ of DM. The concentration of $\mathrm{E}_{2}$ and the $\mathrm{E}_{2}$ :progesterone $\left(\mathbf{P}_{4}\right)$ ratio in $\mathrm{E}_{2}$-active follicles were lower in cows fed flaxseed than in those fed sunflower. Thangavelu et al. (2007) reported numerically, but not significantly, lower $\mathrm{E}_{2}$ concentrations in the FF of dairy cows fed whole flaxseed than in those fed sunflower seed or saturated fat, which is consistent with Zachut et al. (2010b). However, Robinson et al. (2002) observed higher plasma $\mathrm{E}_{2}$ concentrations in cows fed ALA than in those fed LNA, which is associated with higher steroidogenesis of $\mathrm{E}_{2}$ by the dominant follicle.

In Zachut et al. (2010b), the proportion of arachidonic acid $(\mathrm{C} 20: 4 \mathrm{n}-6)$ observed in the $\mathrm{FF}$ was lower in cows fed encapsulated flaxseed oil than in the other groups. Steroid synthesis requires increased expression of steroidogenic acute regulatory protein (StAR), which mediates the transfer of cholesterol from the cytosol to the inner mitochondrial membrane (Stocco and Clark, 1996). Because expression of StAR is upregulated by arachidonic acid (Wang et al., 2000), the lower level of arachidonic acid in the FF of cows fed flaxseed oil may be associated with the decrease in $\mathrm{E}_{2}$ synthesis rate.

In another study (Moallem et al., 2013), cows were supplemented with encapsulated SFA, flaxseed oil, or fish oil. No differences were observed among the dietary groups in concentrations or contents of $\mathrm{P}_{4}$, androstenedione, or $\mathrm{E}_{2}$ in the $\mathrm{FF}$ of preovulatory $\mathrm{E}_{2}$-active follicles that were aspirated in vivo (Moallem et al., 2013). In addition, the diameters and volumes of the follicles, as well as $\mathrm{E}_{2}: \mathrm{P}_{4}$ ratio, were similar among all of the groups. However, in another study, enhanced $\mathrm{P}_{4}$ concentrations in the follicles were observed in ewes fed a mixture of flaxseed oil and fish oil (Wonnacott et al., 2010). In contrast to other studies, Ambrose et al. (2006) found increased diameter of ovulatory follicles in cows fed rolled flaxseed.

\section{IVF Performance}

In Zachut et al. (2010b), cows were supplemented with encapsulated flaxseed oil or sunflower oil at $3.8 \%$ of DM. Ovum pick-up, in vitro maturation, and oocyte 
fertilization were performed. The cleavage rate in the cows supplemented with flaxseed oil was higher than in the control group (49.2 and $41.5 \%$, respectively), but not higher than the sunflower group. Homa and Brown (1992) cultured bovine oocytes with LNA and noted a reduction in the spontaneous breakdown of germinal vesicles compared with that in oocytes cultured without FA. In Hochi et al. (1999), embryos cultured with LNA exhibited reduced development to the morula stage and further reduced development to the blastocyst stage compared with embryos cultured without LNA. In addition, SFA have been shown to be detrimental to oocyte competence and development; Leroy et al. (2005) demonstrated that PA and SA reduce the cleavage and development rates of blastocysts in vitro compared with the effect of OA. In addition, Thangavelu et al. (2007) found fewer blastomeres in cows fed SFA than in those fed sunflower or flaxseed oils.

In Moallem et al. (2013), cows were supplemented with encapsulated SFA, flaxseed oil, or fish oil. The cleavage rate was higher in both n-3-supplemented groups (52 and $48 \%$ in encapsulated flaxseed and fish oils groups, respectively) than in the SFA cows (35\%). However, Bilby et al. (2006) observed no differences in oocyte quality or cleavage rate between cows that were fed flaxseed at $140 \mathrm{~g} / \mathrm{d}$ or LNA at $71 \mathrm{~g} / \mathrm{d}$ under heatstress conditions. The differences in the results between these studies may be attributed to season (i.e., summer vs. winter); moreover, Zeron et al. (2001) showed that UFA contents in oocytes and granulosa cells were lower in summer than in winter. In another study, dairy cows were fed several UFA and no effect on oocyte quality or cleavage rate was observed (Fouladi-Nashta et al., 2009); however, in that study, the cows were fed for a short time $-25 \mathrm{~d}$ - and no alterations were found in the FA profile of granulosa cells, which may account for the lack of response to FA supplementation. The n-3 FA may affect maturation and development of oocytes directly through alterations in membrane FA composition (Bender et al., 2010) or indirectly by influencing the concentrations of hormones and metabolites in the FF surrounding the oocytes (Fouladi-Nashta et al., 2009).

The effects of PUFA on the cellular and molecular pathways involved in the fertilization process in cows are largely unknown. Santos et al. (2008) and Cerri et al. (2009) concluded that increased intake of PUFA might affect the FA composition of reproductive tissues and thereby improve fertilization rate and embryonic development.

Although considerable differences were observed in the incorporation of different n-3 FA from dietary flaxseed or fish oil into ovarian compartments, in Moal- lem et al. (2013) study, no differences were observed in the beneficial effects of different n-3 FA from different sources on folliculogenesis, oocyte quality, or IVF performance. These results suggest that supplementing cows with flaxseed - the most widely available botanical source of n-3 FA and preferable to fish oil in ruminant nutrition - is a satisfactory approach to achieving improvements in folliculogenesis and oocyte fertilization.

Collectively, these effects on oocyte competence may be due to changes in the oocyte's surroundings or to incorporation of specific FA into the cell membrane and the intracellular environment. Although some beneficial effects of ALA on oocyte quality have been demonstrated, more research is needed to elucidate the mechanism behind these positive outcomes.

\section{Effects of n-3 FA Dietary Supplementation on Bulls' Reproductive Systems}

Bull Plasma. Basal plasma ALA concentration in cows is $1.03 \%$ (Zachut et al., 2010a), whereas in fertile bulls fed encapsulated SFA, flaxseed oil, or fish oil for 13 wk, it was 3-fold higher (3.67\%; Moallem et al., 2015). This may be attributed to the high turnover of long-chain FA in cows due to their intensive transfer to milk fat. Interestingly, the concentration of ALA in the plasma is 2-fold greater in women than in men (Burdge and Wootton, 2002), suggesting sex differences in ALA metabolism. No increase in the longer n-3 FA (EPA, DPAn-3, or DHA) was observed in the flaxseed oil-supplemented bulls, which might indicate the absence, or at least low rate, of elongation and desaturation of ALA in the liver of bulls. In humans, a moderate increase in EPA was observed in response to ALA supplementation (Arterburn et al., 2006). However, the increase in plasma DHA in the fish oil-fed bulls was 28 -fold higher than in other groups (Moallem et al., 2015).

Effects on Sperm and Seminal Fluid FA Composition. The incorporation of dietary FA into sperm was found to be relatively slow compared with that into plasma, and differences were only prominent and statistically significant after 6 to 7 wk (Moallem et al., 2015; Figure 2). Similar results were found in a study conducted in boars (Rooke et al., 2001). Spermatogenesis in bulls lasts for $61 \mathrm{~d}$ (Senger, 2003); the sperm's membrane composition is altered during its passage through the epididymis (Senger, 2003). Because the differences in sperm FA profile due to dietary supplementation of long-chain FA only became apparent after $\sim 35$ d (Moallem et al., 2015; Figure 2), it may be concluded that FA composition of the sperm membrane is finalized during the early process of spermatogenesis (up to $25 \mathrm{~d}$ ), and that the incorporation of dietary PUFA 

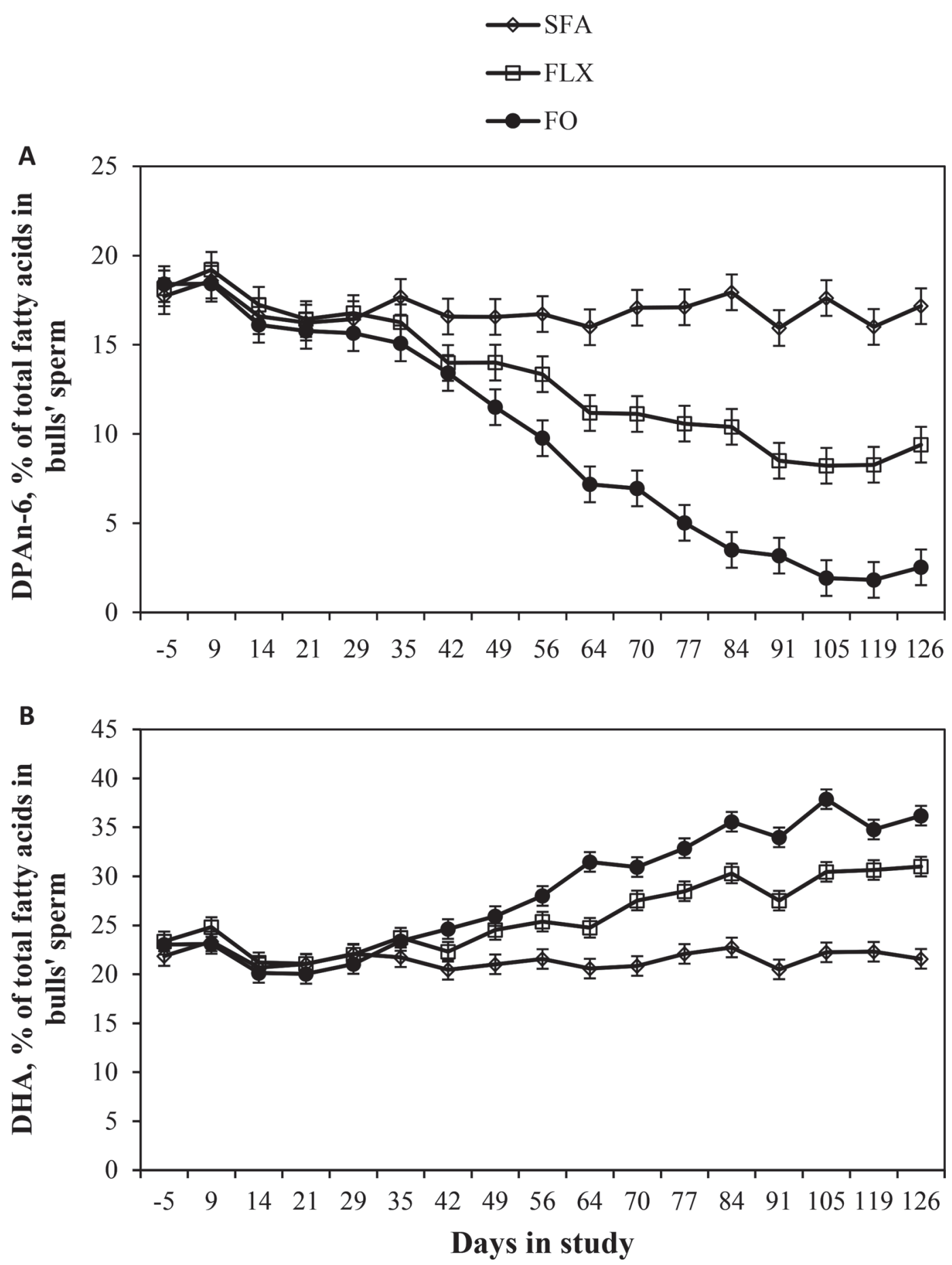

Figure 2. Changes over time in concentrations of (A) n-6 docosapentaenoic acid (DPAn-6) and (B) docosahexaenoic acid (DHA) in the sperm of bulls supplemented with encapsulated fats: SFA at $360 \mathrm{~g} / \mathrm{d}$ per bull $(\diamond)$; flaxseed oil (FLX) at $450 \mathrm{~g} / \mathrm{d}$ per bull providing $84.2 \mathrm{~g} / \mathrm{d} \alpha-$ linolenic

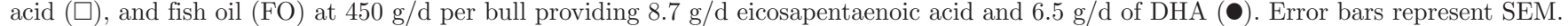

occurred only during this period. From 25 d on, modifications of membrane FA composition due to dietary supplementation are limited and negligible.

In Moallem et al. (2015), bulls were supplemented with high amounts of ALA, and indeed the proportion of this FA was remarkably increased in plasma, but not in sperm. On the other hand, the proportion of DHA in the sperm of bulls supplemented with flaxseed oil (providing only ALA) increased by 5 percentage points, indicating intensive desaturation and elonga- 
tion of ALA into the longer n-3 FA in the testes. It is also interesting that proportions of the shorter n-3 FA, such as C20:4n-3, EPA, and DPAn-3, did not increase in these bulls, although the metabolic pathway of de novo DHA synthesis passes through all of these n- 3 FA (Lenzi et al., 1996). This phenomenon emphasizes the unique role of DHA in spermatogenesis. In Moallem et al. (2015), the dietary treatments did not alter the proportion of overall FA families in the sperm (SFA, MUFA, and PUFA), and the only prominent difference was the clear exchange between DPAn-6 and DHA (Figure 2).

The proportion of DHA in the seminal fluid in Moallem et al. (2015) was similar between bulls supplemented with flaxseed oil and fish oil; however, the DHA content was $\sim 13$ to 14 percentage points lower than that in sperm. Seminal fluid originates mainly from the prostate and seminal vesicles. Because the plasma DHA concentration was relatively low, it is plausible that the desaturation and elongation processes were local; that is, they occurred in the testes. The trend toward lower DPAn-6 and higher DHA proportions was also observed in the seminal fluid. However, the proportions of DHA and total n-3 FA in the seminal fluid were about half those in the sperm (Moallem et al., 2015).

Effects on Physiological Parameters of Fresh and Frozen-Thawed Semen. Motility and progressive motility in fresh semen were higher in bulls supplemented with flaxseed oil than controls (Moallem et al., 2015). In addition, in Moallem et al. (2015), the fading rate of semen (calculated as the progressive motility of cryopreserved relative to that of fresh samples) of the flaxseed oil-supplemented bulls tended to be lower than that of the SFA-fed bulls. In rabbits, supplementation of flaxseed oil increased the percentage of live cells and their linear speed, with no improvement in other quality parameters (Mourvaki et al., 2010). In a study conducted in humans, dietary supplementation with EPA and DHA improved sperm cell counts and concentration in infertile men with idiopathic oligoasthenoteratospermia (Safarinejad et al., 2010); this was not found by Moallem et al. (2015) in the n-3supplemented groups. However, it should be noted that although the human study was conducted on infertile men (Safarinejad et al., 2010), the study by Moallem et al. (2015) was conducted on bulls with improved fertility, which may diminish the effects of PUFA on sperm counts.

In monkey sperm, $99 \%$ of the DHA is present in the flagella, mainly in the phospholipid fraction of the membrane (Connor et al., 1998), which may contribute to membrane fluidity and, consequently, sperm tail motility. In a sophisticated study by Roqueta-Rivera et al. (2011), the role of DHA in spermatogenesis in the absence of DPAn-6 was demonstrated; in this study, delta-6-desaturase-null mice were supplemented with either arachidonic acid or DHA; spermatogenesis was completely restored in the DHA-supplemented mice, whereas arachidonic acid supplementation was less effective. Moreover, the DHA-supplemented mice exhibited normal spermatogenesis in the absence of DPAn-6, which means that these FA may be interchangeable, and DPAn-6 is dispensable for sperm function as long as there is sufficient DHA (Roqueta-Rivera et al., 2011).

In summary, dietary n-3 FA from different sources are incorporated into the plasma, seminal fluid, and sperm cells in bulls. The incorporation of dietary long-chain FA into sperm was evident only after $35 \mathrm{~d}$. Moreover, there is evidence that de novo elongation and desaturation of short into longer n-3 FA occurs in the testes. Enrichment of sperm with n-3 FA improves the survival and quality of fresh and frozen-thawed semen, suggesting that the ratio between these $2 \mathrm{FA}$ plays an important role in sperm function. In addition, as discussed above for females, flaxseed oil, which is the most widely available botanical source of n-3 FA and is preferable to fish oil in ruminant nutrition, provides a satisfactory approach to achieving improvements in sperm quality.

\section{Supplementation of n-3 FA to Late-Pregnant Cows on Plasma FA Composition in Their Newborn Calves}

Polyunsaturated FA, and especially those from the n-3 family, play an important physiological role during pregnancy, as they are critical for the development of the central nervous system (Koletzko et al., 2007) and reproductive system (Stoffel et al., 2008) of the unborn calf. However, epitheliochorial placentas are less permeable to free FA than hemochorial ones (Battaglia and Meschia, 1988), and the placental transport of shortand long-chain FA in ruminants is limited (Bell, 1993). Furthermore, FA in the maternal circulation are the main source of FA for the fetus (Campbell et al., 1994). The role of n-3 FA in the unborn calf's development on the one hand and the limited transport of long-chain FA through the ruminant's placenta on the other, raise a very interesting question with regard to supplementation of these unique FA to unborn calves.

In a study conducted by Moallem and Zachut (2012), cows at $256 \mathrm{~d}$ of pregnancy were supplemented with encapsulated SFA, flaxseed oil, or fish oil. Blood samples were taken from the newborn calves immediately after birth (before colostrum offering). The proportions of total n-3 and total n-6 PUFA were found to be higher in the dams than in the calves: 2.3 versus $1.1 \%$ and 36.6 versus $13.3 \%$, respectively. The ALA was barely transferred from the dams into the calves' blood (Moallem 
and Zachut, 2012); this is consistent with the findings of de Groot et al. (2004), where supplementation of pregnant women with ALA did not enhance its levels in umbilical cord blood. However, the proportion of DHA was 1.9 times higher in the fish oil-treated calves than in controls, but there were no differences between groups in the plasma proportions of ALA, EPA, or DPAn-3 (Moallem and Zachut, 2012). This pattern of maternal diet effects on FA profile of plasma of the newborn calf was also demonstrated in Garcia et al. (2014). The maternofetal transfer of FA is considered to depend, in part, on concentration gradients across the placenta (Hay, 1994). This was also demonstrated in Moallem and Zachut (2012), in which the magnitude of DHA transfer was influenced by the concentration of this FA in the dams' blood. Similarly, supplementation of pregnant women with DHA has been shown to increase its levels in the plasma and red blood cell lipids in the infant at birth (Connor et al., 1996).

The vast differences in FA profiles between dams and calves observed by Moallem and Zachut (2012) might be explained by placental desaturation of FA or selective uptake of FA by placental FA-binding proteins; however, although dams had a much higher proportion of plasma ALA (a precursor of DHA), higher DHA proportions in the plasma of calves born from dams supplemented with flaxseed oil were not observed. This could be explained by active placental FA-binding proteins, which have been demonstrated in humans, in which placental transfer of DHA involves a multistep process of uptake and intercellular translocation by several membrane-associated and cytosolic FA-binding proteins that prefer n- 6 and n-3 FA over nonessential FA (Campbell et al., 1998; Innis, 2005; Hanebutt et al., 2008). A placental FA-binding protein was also identified in sheep (Campbell et al., 1994); however, to the best of my knowledge, none have been found in the bovine placenta. Regardless of the effects during the embryonic stage, enriching the newborn with these essential FA may exert positive effects on calf health and performance at a very early age (Hill et al., 2011). However, further sophisticated studies are required to investigate the exact mechanism of transfer of n-3 FA, and specifically of DHA, through the bovine placenta, and the effects on newborn calves' health and performance.

\section{INVOLVEMENT OF n-3 FA IN THE IMMUNE SYSTEM}

Involvement of FA, and especially PUFA, in the immune system has been well established by many in vivo and in vitro studies, as summarized by Sordillo (2016). Changes in the composition of the immune cells affect the immune response directly in several ways. The type of FA in the membrane phospholipid can affect both membrane fluidity and functioning of immune cells (Raphael and Sordillo, 2013). Clarke (2004) and Lee et al. (2010) found that EPA and DHA perform anti-inflammatory functions through direct or indirect inhibitory mechanisms. These effects of specific FA on induced inflammation seem to act through modification of several genes that are central to the inflammatory response (Lee et al., 2010). The functional properties of lymphocytes and mononuclear cells in transition cows are also modulated by dietary supplementation of n-3 FA (Lessard et al., 2004). In addition, Silvestre et al. (2011) showed that the n-3 FA profile of neutrophils was increased when dairy cows were supplemented with n-3 FA from fish oil, and the production of tumor necrosis factor $\alpha$ (TNF- $\alpha)$ by neutrophils stimulated with LPS was attenuated compared with those from cows fed palm oil. Contreras et al. (2012a,b) used cultured bovine endothelial cells to show that proinflammatory responses could be mitigated in response to high free FA concentrations that mimicked intense lipid mobilization in transition cows. These in vitro studies provided the first direct evidence that reduced inflammatory responses might be a result of shifts in oxylipid profiles following n-3 supplementation (Contreras et al., 2012a). Elongation of ALA into DHA was demonstrated in the testis (Moallem et al., 2015) or into DPAn-3 in the ovary (Moallem et al., 2013), which may indicate the potential of other tissues to elongate the short-chain n-3 FA ALA into longer FA (EPA, DPA, and DHA). This means that supplementation of ALA from flaxseed may be a satisfactory means of exerting positive effects on the immune system.

\section{EFFECTS OF n-3 SUPPLEMENTATION ON HEALTH}

Several studies have reported beneficial effects of n-3 FA on health aspects in humans and nonruminant animals, such as metabolic syndrome, brain metabolic abnormalities (Simopoulos, 2013), inflammatory diseases (Calder, 2006), and the immune system (Miles and Calder, 1998). Abnormalities in membrane FA composition, especially deficiencies in $n-3 \mathrm{FA}$, may be involved in the pathogenesis of disorders linked to insulin resistance (Storlien et al., 1991; Borkman et al., 1993), which may be associated with the periparturient metabolism of high-yielding dairy cows; this disorder can be prevented by inclusion of n-3 FA in the diet (Storlien et al., 1991).

Because of the complexity of performing large field studies to assess the health effects of dietary supplementation of n-3 FA, very few studies have investigated this issue in cattle. In a small-scale study $(\mathrm{n}=35)$, Petit et al. (2007) found fewer diseased animals among 


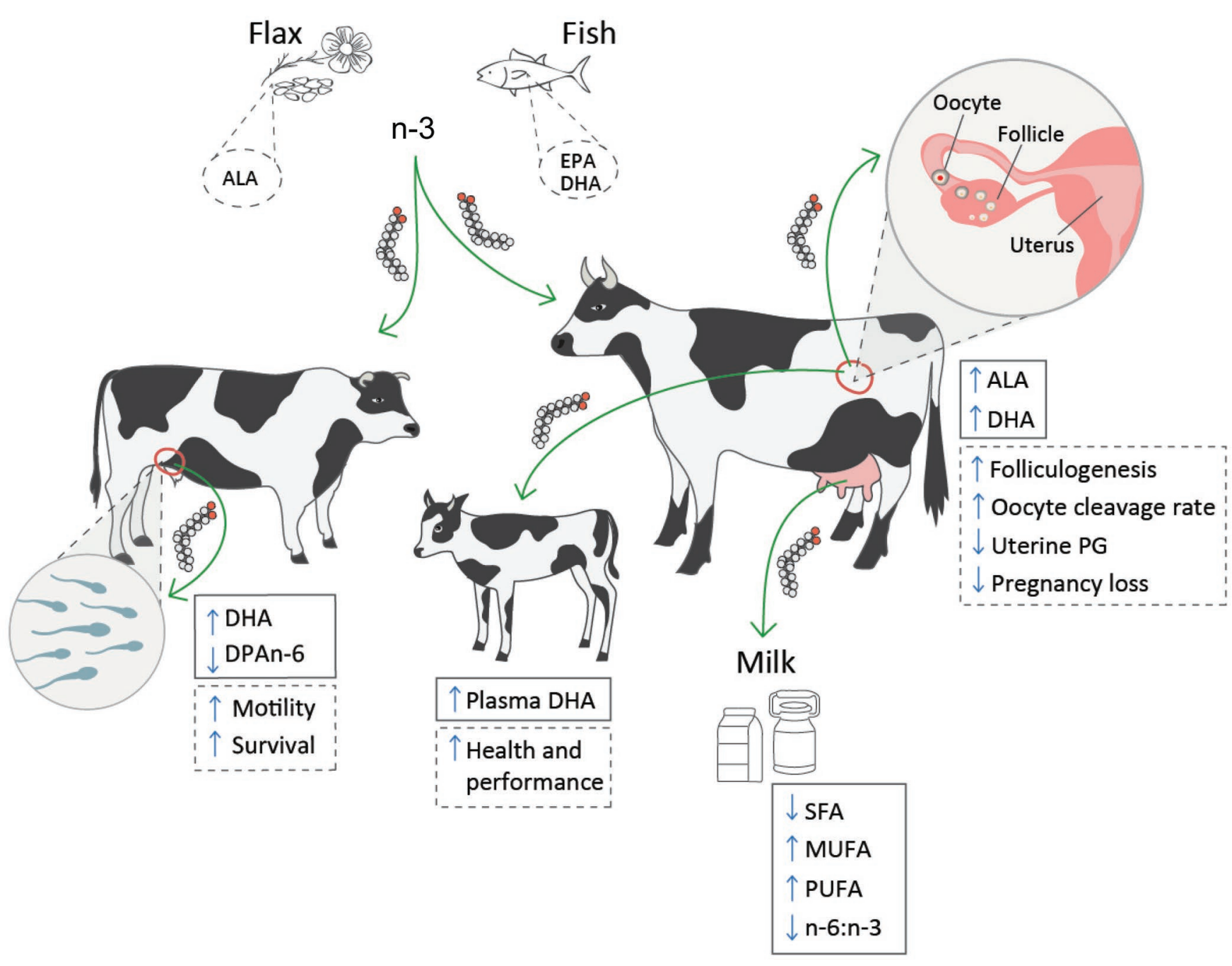

Legend:

\section{Altered FA composition :-- Change in function}

Figure 3. Roles of dietary n-3 (omega-3) fatty acids (FA) in dairy cattle: effects on FA composition in cow, bull, and calf tissues, and the subsequent effect on function. ALA $=\alpha$-linolenic acid; EPA $=$ eicosapentaenoic acid; DPAn- $6=\mathrm{n}-6$ docosapentaenoic acid; DHA $=$ docosahexaenoic acid; $\mathrm{PG}=$ prostaglandin $\mathrm{F}_{2 \alpha}$.

cows fed whole flaxseed than among those fed a control diet or one supplemented with Energy Booster (Milk Specialties Co., Dundee, IL). In our large-scale field study (data not yet published), 276 multiparous cows were supplemented prepartum with EF at $4 \%$ of DM, and postpartum with $5 \%$ of the same supplement, and were compared with 240 cows fed a common diet; EF supplementation decreased the incidence of ketosis and severe metritis, and remarkably reduced mortality. Al- though several studies have demonstrated beneficial effects on health of dairy cows, further studies are needed to confirm these findings.

\section{CONCLUSIONS}

This comprehensive review demonstrates the involvement and influence of $n-3$ FA in biological systems and processes in dairy cattle, as illustrated in Figure 3. Di- 
etary supplementation of n-3 FA from flaxseed oil and fish oil either decreased or had no effect on DMI, milk yield, and milk protein, whereas milk fat decreased in most of the studies. Of special interest to human nutrition are the effects of dietary supplementation with n-3 FA on milk fat composition; it enhances the n-3 FA content, decreases the n-6:n-3 ratio, reduces SFA, and enhances the proportions of MUFA and PUFA, all of which are desirable in human nutrition. Regarding the effects of n-3 FA on the reproductive system in cattle, the incorporation of dietary n-3 FA into the ovarian compartments, bulls' sperm, and the unborn calf through the placenta reveals selective uptake mechanisms, with different infiltration rates of specific FA into specific tissues. This mechanism highlights the precise roles of each n-3 FA in different tissues. Many, but not all, of the studies demonstrated beneficial effects of dietary supplementation of n-3 FA on the reproductive system in females and males. In addition, the involvement of long-chain FA in immune system function was reviewed, and, although few studies have investigated the effects on health, some of them showed positive effects. From this review, it can be concluded that the beneficial effects obtained from feeding n-3 FA, at least for the reproductive system in cows and bulls, can be achieved with supplementation of ALA from flaxseed, whereas no advantage was seen in feeding the longer n-3 FA from fish oil-EPA and DHAover feeding linseeds alone. Another important point is the time required for incorporation of dietary n-3 FA into the target tissues; this was particularly salient in bulls, where a period of 6 to $7 \mathrm{wk}$ is required to achieve the expected infiltration of dietary n-3 FA into sperm, but it also applies in cows. In summary, this review provides a broad perspective on the role of n-3 FA in cattle, confirming the involvement and importance of these FA in many organs and tissues, and the promising effects of dietary supplementation of these unique FA to dairy cattle.

\section{REFERENCES}

AbuGhazaleh, A. A., D. J. Schingoethe, A. R. Hippen, K. F. Kalscheur, and L. A. Whitlock. 2002. Fatty acid profiles of milk and rumen digesta from cows fed fish oil, extruded soybeans, or their blend. J. Dairy Sci. 85:2266-2276.

Akraim, F., M. C. Nicot, P. Juaneda, and F. Enjalbert. 2007. Conjugated linolenic acid (CLnA), conjugated linoleic acid (CLA) and other biohydrogenation intermediates in plasma and milk fat of cows fed raw or extruded linseed. Animal 1:835-843.

Allen, M. S. 2000. Effects of diet on short-term regulation of feed intake by lactating dairy cows. J. Dairy Sci. 83:1598-1624.

Ambrose, D. J., J. P. Kastelic, R. Corbett, P. A. Pitney, H. V. Petit, J. A. Small, and P. Zalkovic. 2006. Lower pregnancy losses in lactating dairy cows fed a diet enriched in a-linolenic acid. J. Dairy Sci. 89:3066-3074.
Arterburn, L. M., E. B. Hall, and H. Oken. 2006. Distribution, interconversion, and dose response of $\mathrm{n}-3$ fatty acids in humans. Am. J. Clin. Nutr. 83:1467S-1476S.

Battaglia, F. C., and G. Meschia. 1988. Fetal nutrition. Annu. Rev. Nutr. 8:43-61.

Baumgard, L. H., J. K. Sangster, and D. E. Bauman. 2001. Milk fat synthesis in dairy cows is progressively reduced by increasing supplemental amounts of trans-10, cis-12 conjugated linoleic acid (CLA). J. Nutr. 131:1764-1769.

Bell, A. W. 1993. Pregnancy and fetal metabolism. Page 405 in Quantitative Aspects of Ruminant Digestion and Metabolism. J. M. Forbes and J. France, ed. CAB International, Oxford, UK.

Bender, K., S. Walsh, A. C. O. Evans, T. Fair, and L. Brennan. 2010 Metabolite concentrations in follicular fluid may explain differences in fertility between heifers and lactating cows. Reproduction 139:1047-1055.

Bilby, T. R., J. Block, B. C. do Amaral, O. Sa Filho, F. T. Silvestre, P. J. Hansen, C. R. Staples, and W. W. Thatcher. 2006. Effects of dietary unsaturated fatty acids on oocyte quality and follicular development in lactating dairy cows in summer. J. Dairy Sci. 89:3891-3903

Blauwiekel, R. W. H. Hoover, S. D. Slider, and T. K. Miller. 1990 Effects of fish meal protein supplementation on milk yield and composition and blood constituents of dairy cows. J. Dairy Sci. 73:3217-3221.

Borkman, M., L. H. Storlien, D. A. Pan, A. B. Jenkins, D. J. Chisholm, and L. V. Campbell. 1993. The relation between insulin sensitivity and the fatty-acid composition of skeletal-muscle phospholipids. N. Engl. J. Med. 328:238-244.

Bremmer, D. R., L. D. Ruppert, J. H. Clark, and J. K. Drackley. 1998. Effects of chain length and unsaturation of fatty acid mixtures infused into the abomasum of lactating dairy cows. J. Dairy Sci. $81: 176-188$

Breslow, J. L. 2006. N-3 fatty acids and cardiovascular disease. Am. J. Clin. Nutr. 83(Suppl.):1477S-1482S.

Burdge, G. C., and A. S. Wootton. 2002. Conversion of $\alpha$-linolenic acid to eicosapentaenoic, docosapentaenoic and docosahexaenoic acids in young women. Br. J. Nutr. 88:411-420.

Burke, J. M., C. R. Staples, C. A. Risco, R. L. De La Sota, and W. W. Thatcher. 1997. Effect of ruminant grade menhaden fish meal on reproductive performance of lactating dairy cows. J. Dairy Sci. 80:3386-3398

Calder, P. C. 2006. Polyunsaturated fatty acids and inflammation Prostaglandins Leukot. Essent. Fatty Acids 75:197-202.

Campbell, F. M., P. G. Bush, J. H. Veerkamp, and A. K. Dutta-Roy. 1998. Detection and cellular localization of plasma membraneassociated and cytoplasmic fatty acid-binding proteins in human placenta. Placenta 19:409-415.

Campbell, F. M., M. J. Gordon, and A. K. Dutta-Roy. 1994. Plasma membrane fatty acid-binding protein (FABPpm) of the sheep placenta. Biochim. Biophys. Acta 1214:187-192.

Cant, J. P., A. H. H. Fredeen, T. MacIntyre, J. Gunn, and N. Crowe. 1997. Effect of fish oil and monensin on milk composition in dairy cows. Can. J. Anim. Sci. 77:125-131.

Cerri, R. L. A., S. O. Juchem, R. C. Chebel, H. M. Rutigliano, R. G. S. Bruno, K. N. Galvao, W. W. Thatcher, and J. E. P. Santos. 2009 Effect of fat source differing in fatty acid profile on metabolic parameters, fertilization, and embryo quality in high-producing dairy cows. J. Dairy Sci. 92:1520-1531.

Childs, S., A. A. Hennessy, J. M. Sreenan, D. C. Wathes, Z. Cheng, C. Stanton, M. G. Diskin, and D. A. Kenny. 2008. Effect of level of dietary n-3 polyunsaturated fatty acid supplementation on systemic and tissue fatty acid concentrations and on selected reproductive variables in cattle. Theriogenology 70:595-611.

Chilliard, Y., F. Glasser, A. Ferlay, L. Bernard, J. Rouel, and M. Doreau. 2007. Diet, rumen biohydrogenation, cow and goat milk fat nutritional quality: A review. Eur. J. Lipid Sci. Technol. 109:828-855.

Chilliard, Y., C. Martin, J. Rouel, and M. Doreau. 2009. Milk fatty acids in dairy cows fed whole crude linseed, extruded linseed, or 
linseed oil, and their relationship with methane output. J. Dairy Sci. 92:5199-5211.

Clandinin, M. T., S. Cheema, C. J. Field, M. L. Garg, J. Venkatraman, and T. R. Clandinin. 1991. Dietary fat: Exogenous determination of membrane structure and cell function. FASEB J. 5:2761-2769.

Clarke, S. D. 2004. The multi-dimensional regulation of gene expression by fatty acids: Polyunsaturated fats as nutrient sensors. Curr. Opin. Lipidol. 15:13-18.

Connor, W. E., D. S. Lin, D. P. Wolf, and M. Alexander. 1998. Uneven distribution of desmosterol and docosahexaenoic acid in the heads and tails of monkey sperm. J. Lipid Res. 39:1404-1411.

Connor, W. E., R. Lowensohn, and L. Hatcher. 1996. Increased docosahexaenoic acid levels in newborn infants by administration of sardines and fish oil during pregnancy. Lipids 31:S183-S187.

Contreras, G. A., S. A. Mattmiller, W. Raphael, J. C. Gandy, and L. M. Sordillo. 2012a. Enhanced n-3 phospholipid content reduces inflammatory responses in bovine endothelial cells. J. Dairy Sci. 95:7137-7150.

Contreras, G. A., W. Raphael, S. A. Mattmiller, J. Gandy, and L. M. Sordillo. 2012b. Nonesterified fatty acids modify inflammatory response and eicosanoid biosynthesis in bovine endothelial cells. J. Dairy Sci. 95:5011-5023.

Côrtes, C., R. Kazama, D. da Silva-Kazama, C. Benchaar, L. M. Zeoula, G. T. Santos, and H. V. Petit. 2011. Digestion, milk production and milk fatty acid profile of dairy cows fed flax hulls and infused with flax oil in the abomasum. J. Dairy Res. 78:293-300.

de Groot, R. H., G. Hornstra, A. C. van Houwelingen, and F. Roumen. 2004. Effect of alpha-linolenic acid supplementation during pregnancy on maternal and neonatal polyunsaturated fatty acid status and pregnancy outcome. Am. J. Clin. Nutr. 79:251-260.

Deckelbaum, R. J., T. Worgall, and T. Seo. 2006. N-3 fatty acids and gene expression. Am. J. Clin. Nutr. 83(Suppl.):1520S-1525S.

Donovan, D. C., D. J. Schingoethe, R. J. Baer, J. Ryali, A. R. Hippen, and S. T. Franklin. 2000. Influence of dietary fish oil on conjugated linoleic acid and other fatty acids in milk fat from lactating dairy cows. J. Dairy Sci. 83:2620-2628.

Doreau, M., and Y. Chilliard. 1997. Effects of ruminal or postruminal fish oil supplementation on intake and digestion in dairy cows. Reprod. Nutr. Dev. 37:113-124.

Drackley, J. K., T. H. Klusmeyer, A. M. Trusk, and J. K. Clark. 1992. Infusion of long-chain fatty acids varying in saturation and chain length into the abomasum of lactating dairy cows. J. Dairy Sci. 75:1517-1526.

Elmore, J. S., S. L. Cooper, M. Enser, D. S. Mottram, L. A. Sinclair, R. G. Wilkinson, and J. D. Wood. 2005. Dietary manipulation of fatty acid composition in lamb meat and its effect on the volatile aroma compounds of grilled lamb. Meat Sci. 69:233-242.

Evans, A. C. O., F. Mossa, S. W. Walsh, D. Scheetz, F. JimenezKrassel, J. L. H. Ireland, G. W. Smith, and J. J. Ireland. 2012. Effects of maternal environment during gestation on ovarian folliculogenesis and consequences for fertility in bovine offspring. Reprod. Domest. Anim. 47(Suppl. 4):31-37.

Ferlay, A., M. Doreau, C. Martin, and Y. Chilliard. 2013. Effects of incremental amounts of extruded linseed on the milk fatty acid composition of dairy cows receiving hay or corn silage. J. Dairy Sci. 96:6577-6595.

Fievez, V., B. Vlaeminck, T. Jenkins, F. Enjalbert, and M. Doreau. 2007. Assessing rumen biohydrogenation and its manipulation in vivo, in vitro and in situ. Eur. J. Lipid Sci. Technol. 109:740-756.

Fouladi-Nashta, A. A., K. E. Wonnacott, C. G. Gutierrez, J. G. Gong, K. D. Sinclair, P. C. Garnsworthy, and R. Webb. 2009. Oocyte quality in lactating dairy cows fed on high levels of n-3 and n-6 fatty acids. Reproduction 138:771-781.

Fuentes, M. C., S. Calsamiglia, C. Sánchez, A. González, J. R. Newbold, J. E. P. Santos, L. M. Rodríguez-Alcalá, and J. Fontecha. 2008. Effect of extruded linseed on productive and reproductive performance of lactating dairy cows. Livest. Sci. 113:144-154.

Garcia, M., L. F. Greco, M. G. Favoreto, R. S. Marsola, L. T. Martins, R. S. Bisinotto, J. H. Shin, A. L. Lock, E. Block, W. W. Thatcher, J. E. P. Santos, and C. R. Staples. 2014. Effect of supplementing fat to pregnant nonlactating cows on colostral fatty acid profile and passive immunity of the newborn calf. J. Dairy Sci. 97:392405.

Gonthier, C., A. F. Mustafa, D. R. Ouellet, P. Y. Chouinard, R. Berthiaume, and H. V. Petit. 2005. Feeding micronized and extruded flaxseed to dairy cows: Effects on blood parameters and milk fatty acid composition. J. Dairy Sci. 88:748-756.

Hanebutt, F. L., H. Demmelmair, B. Schiessl, E. Larqué, and B. Koletzko. 2008. Long-chain polyunsaturated fatty acid (LC-PUFA) transfer across the placenta. Clin. Nutr. 27:685-693.

Harvatine, K. J., and M. S. Allen. 2006. Effects of fatty acid supplements on milk yield and energy balance of lactating dairy cows. J. Dairy Sci. 89:1081-1091.

Hay, W. W. Jr. 1994. Placental transport of nutrients to the fetus. Horm. Res. 42:215-222.

Heravi Moussavi, A. R., R. O. Gilbert, T. R. Overton, D. E. Bauman, and W. R. Butler. 2007. Effects of feeding fish meal and n-3 fatty acids on ovarian and uterine responses in early lactating dairy cows. J. Dairy Sci. 90:145-154.

Hill, T. M., M. J. VandeHaar, L. M. Sordillo, D. R. Catherman, H. G. Bateman, and R. L. Schlotterbeck. 2011. Fatty acid intake alters growth and immunity in milk-fed calves. J. Dairy Sci. 94:39363948.

Hochi, S., K. Kimura, and A. Hanada. 1999. Effect of linoleic-acid albumin in the culture medium on freezing sensitivity of in vitro produced bovine morulae. Theriogenology 52:497-504.

Homa, S. T., and C. A. Brown. 1992. Changes in linoleic acid during follicular development and inhibition of spontaneous breakdown of germinal vesicles in cumulus-free bovine oocytes. J. Reprod. Fertil. 94:153-160.

Hurtaud, C., F. Faucon, S. Couvreur, and J. L. Peyraud. 2010. Linear relationship between increasing amounts of extruded linseed in dairy cow diet and milk fatty acid composition and butter properties. J. Dairy Sci. 93:1429-1443.

Innis, S. M. 2005. Essential fatty acid transfer and fetal development. Placenta 26(Suppl. A):S70-S75.

Innis, S. M. 2008. Dietary omega 3 fatty acids and the developing brain. Brain Res. 1237:35-43.

Jenkins, T. C. 1993. Lipid metabolism in the rumen. J. Dairy Sci. 76:3851-3863.

Keady, T. W. J., C. S. Mayne, and D. A. Fitzpatrick. 2000. Effects of supplementation of dairy cattle with fish oil on silage intake, milk yield and milk composition. J. Dairy Res. 67:137-153.

Kennelly, J. J. 1996. The fatty acid composition of milk as influenced by feeding oilseeds. Anim. Feed Sci. Technol. 60:137-152.

Khan, T. A., N. Khan, M. Ashraf, N. A. Qureshi, M. S. Mugha, and G. Abbas. 2012. Source, production and chemical composition of fish meal in Pakistan. J. Vet. Anim. Sci. (Lahore) 2:65-71.

Kliem, K. E., P. C. Aikman, D. J. Humphries, R. Morgan, K. J. Shingfield, and D. I. Givens. 2009. Effect of replacing calcium salts of palm oil distillate with extruded linseeds on milk fatty acid composition in Jersey and Holstein cows. Animal 3:1754-1762.

Koletzko, B., E. Larqué, and H. Demmelmair. 2007. Placental transfer of long-chain polyunsaturated fatty acids (LC-PUFA). J. Perinat. Med. 35(Suppl. 1):S5-S11.

Leduc, M., M. P. Létourneau-Montminy, R. Gervais, and P. Y. Chouinard. 2017. Effect of dietary flax seed and oil on milk yield, gross composition, and fatty acid profile in dairy cows: A meta-analysis and meta-regression. J. Dairy Sci. 100:8906-8927.

Lee, J. Y., L. Zhao, and D. H. Hwang. 2010. Modulation of pattern recognition receptor-mediated inflammation and risk of chronic diseases by dietary fatty acids. Nutr. Rev. 68:38-61.

Lee, Y. J., and T. C. Jenkins. 2011. Biohydrogenation of linolenic acid to stearic acid by the rumen microbial population yields multiple intermediate conjugated diene isomers. J. Nutr. 141:1445-1450.

Lenzi, A., M. Picardo, L. Gandini, and F. Dondero. 1996. Lipids of the sperm plasma membrane: From polyunsaturated fatty acids considered as markers of sperm function to possible scavenger therapy. Hum. Reprod. Update 2:246-256.

Leroy, J. L., R. G. Sturmey, V. Van Hoeck, J. De. Bie, P. J. McKeegan, and P. E. Bols. 2014. Dietary fat supplementation and the conse- 
quences for oocyte and embryo quality: Hype or significant benefit for dairy cow reproduction? Reprod. Domest. Anim. 49:353-361.

Leroy, J. L., T. Vanholder, B. Mateusen, A. Christophe, G. Opsomer, A. de Kruif, G. Genicot, and A. Van Soom. 2005. Non-esterified fatty acids in follicular fluid of dairy cows and their effect on developmental capacity of bovine oocytes in vitro. Reproduction 130:485-495.

Lessard, M., N. Gagnon, D. L. Godson, and H. V. Petit. 2004. Influence of parturition and diets enriched in n- 3 or n- 6 polyunsaturated fatty acids on immune response of dairy cows during the transition period. J. Dairy Sci. 87:2197-2210.

Martin, C., J. Rouel, J. P. Jouany, M. Doreau, and Y. Chilliard. 2008. Methane output and diet digestibility in response to feeding dairy cows crude linseed, extruded linseed, or linseed oil. J. Anim. Sci. 86:2642-2650.

Mattos, R., C. R. Staples, A. Arteche, M. C. Wiltbank, F. J. Diaz, T. C. Jenkins, and W. W. Thatcher. 2004. The effects of feeding fish oil on uterine secretion of $\mathrm{PGF}_{2 \alpha}$, milk composition, and metabolic status of periparturient Holstein cows. J. Dairy Sci. 87:921-932.

Mattos, R., C. R. Staples, and W. W. Thatcher. 2000. Effects of dietary fatty acids on reproduction in ruminants. Rev. Reprod. 5:38-45.

Mattos, R., C. R. Staples, J. Williams, A. Amorocho, M. A. McGuire, and W. W. Thatcher. 2002. Uterine, ovarian, and production responses of lactating dairy cows to increasing dietary concentrations of menhaden fish meal. J. Dairy Sci. 85:755-764.

Miles, E. A., and P. C. Calder. 1998. Modulation of immune function by dietary fatty acids. Proc. Nutr. Soc. 57:277-292.

Moallem, U. 2009. The effects of extruded flaxseed supplementation to high-yielding dairy cows on milk production and milk fatty acid composition. Anim. Feed Sci. Technol. 152:232-242.

Moallem, U., N. Neta, Y. Zeron, M. Zachut, and Z. Roth. 2015. Dietary $\alpha$-linolenic acid from flaxseed oil or eicosapentaenoic and docosahexaenoic acids from fish oil differentially alter fatty acid composition and characteristics of fresh and frozen-thawed bull semen. Theriogenology 83:1110-1120.

Moallem, U., A. Shafran, M. Zachut, I. Dekel, and A. Arieli. 2013. Dietary alpha-linolenic acid (ALA) from flaxseed oil improved folliculogenesis and IVF performance in dairy cows, similar to eicosapentaenoic (EPA) and docosahexaenoic (DHA) acids from fish oil. Reproduction 146:603-614.

Moallem, U., D. Vyas, B. B. Teter, P. Delmonte, M. Zachut, and R. A Erdman. 2012. Transfer rate of $\alpha$-linolenic acid from abomasally infused flaxseed oil into milk fat and the effects on milk fatty acid composition in dairy cows. J. Dairy Sci. 95:5276-5284.

Moallem, U., and M. Zachut. 2012. Short communication: The effects of supplementation of various n-3 fatty acids to late-pregnant dairy cows on plasma fatty acid composition of the newborn calves. J. Dairy Sci. 95:4055-4058.

Mossa, F., S. W. Walsh, S. T. Butler, D. P. Berry, F. Carter, P. Lonergan, G. W. Smith, J. J. Ireland, and A. C. O. Evans. 2012. Low numbers of ovarian follicles $>3 \mathrm{~mm}$ in diameter are associated with low fertility in dairy cows. J. Dairy Sci. 95:2355-2361.

Mourvaki, E., R. Cardinali, A. Dal Bosco, L. Corazzi, and C. Castellini. 2010. Effects of flaxseed dietary supplementation on sperm quality and on lipid composition of sperm subfractions and prostatic granules in rabbit. Theriogenology 73:629-637.

Mustafa, A. F., P. Y. Chouinard, and D. A. Christensen. 2003. Effects of feeding micronized flaxseed on yield and composition of milk from Holstein cows. J. Sci. Food Agric. 83:920-926.

Neveu, C., B. Baurhoo, and A. Mustafa. 2013. Effect of feeding extruded flaxseed with different forage:concentrate ratios on the performance of dairy cows. J. Dairy Sci. 96:3886-3894.

Oeffner, S. P., Y. Qu, J. Just, N. Quezada, E. Ramsing, M. Keller, G. Cherian, L. Goddick, and G. Bobe. 2013. Effect of flaxseed supplementation rate and processing on the production, fatty acid profile, and texture of milk, butter, and cheese. J. Dairy Sci. 96:1177-1188

Omidi, M., S. Rahimi, and M. A. K. Torshizi. 2015. Modification of egg yolk fatty acids profile by using different oil sources. Vet. Res. Forum 6:137-141.
Orsavova, J., L. Misurcova, J. V. Ambrozova, R. Vicha, and J. Mlcek. 2015. Fatty acids composition of vegetable oils and its contribution to dietary energy intake and dependence of cardiovascular mortality on dietary intake of fatty acids. Int. J. Mol. Sci. 16:12871-12890.

Palmquist, D. L. 2009. Omega-3 fatty acids in metabolism, health, and nutrition and for modified animal product foods. Prof. Anim. Sci. 25:207-249.

Petit, H. V. 2002. Digestion, milk production, milk composition, and blood composition of dairy cows fed whole flaxseed. J. Dairy Sci. 85:1482-1490.

Petit, H. V. 2003. Digestion, milk production, milk composition, and blood composition of dairy cows fed formaldehyde treated flaxseed or sunflower seed. J. Dairy Sci. 86:2637-2646.

Petit, H. V. 2010. Review: Feed intake, milk production and milk composition of dairy cows fed flaxseed. Can. J. Anim. Sci. 90:115-127.

Petit, H. V., and C. Benchaar. 2007. Milk production, milk composition, blood composition, and conception rate of transition dairy cows fed different fat sources. Can. J. Anim. Sci. 87:591-600.

Petit, H. V., and C. Côrtes. 2010. Milk production and composition, milk fatty acid profile, and blood composition of dairy cows fed whole or ground flaxseed in the first half of lactation. Anim. Feed Sci. Technol. 158:36-43.

Petit, H. V., R. J. Dewhurst, N. D. Scollan, J. G. Proulx, M. Khalid, W. Haresign, H. Twagiramungu, and G. E. Mann. 2002. Milk production and composition, ovarian function, and prostaglandin secretion of dairy cows fed omega-3 fats. J. Dairy Sci. 85:889-899.

Petit, H. V., C. Germiquet, and D. LeBel. 2004. Effect of feeding whole unprocessed sunflower seeds and flaxseed on milk production, milk composition, and prostaglandin secretion in dairy cows. J. Dairy Sci. 87:3889-3898.

Petit, H. V., M. Ivan, and P. S. Mir. 2005. Effects of flaxseed on protein requirements and $\mathrm{N}$ excretion of dairy cows fed diets with two protein concentrations. J. Dairy Sci. 88:1755-1764.

Petit, H. V., M. F. Palin, and L. Doepel. 2007. Hepatic lipid metabolism in transition dairy cows fed flaxseed. J. Dairy Sci. 90:47804792.

Petit, H. V., and H. Twagiramungu. 2006. Conception rate and reproductive function of dairy cows fed different fat sources. Theriogenology 66:1316-1324.

Piperova, L. S., U. Moallem, B. B. Teter, J. Sampugna, M. P. Yurawecz, K. H. Morehouse, D. Luchini, and R. A. Erdman. 2004. Changes in milk fat in response to dietary supplementation with calcium salts of trans-18:1 or conjugated linoleic fatty acids in lactating dairy cows. J. Dairy Sci. 87:3836-3844.

Pirondini, M., S. Colombini, M. Mele, L. Malagutti, L. Rapetti, G. Galassi, and G. M. Crovetto. 2015. Effect of dietary starch concentration and fish oil supplementation on milk yield and composition, diet digestibility, and methane emissions in lactating dairy cows. J. Dairy Sci. 98:357-372.

Ponter, A. A., A. E. Parsy, M. Saade, J. P. Mialot, C. Ficheux, C. Duvaux-Ponter, and B. Grimard. 2006. Effect of a supplement rich in linolenic acid added to the diet of postpartum dairy cows on ovarian follicle growth, and plasma fatty acid compositions. Reprod. Nutr. Dev. 46:19-29.

Prescott, S. L., and P. Calder. 2004. N-3 polyunsaturated fatty acids and allergic disease. Curr. Opin. Clin. Nutr. Metab. Care 7:123129.

Rabiee, A. R., K. Breinhild, W. Scott, H. M. Golder, E. Block, and I. J. Lean. 2012. Effect of fat additions to diets of dairy cattle on milk production and components: A meta-analysis and metaregression. J. Dairy Sci. 95:3225-3247.

Raphael, W., and L. M. Sordillo. 2013. Dietary polyunsaturated fatty acids and inflammation: The role of phospholipid biosynthesis. Int. J. Mol. Sci. 14:21167-21188.

Robinson, R. S., P. G. Pushpakumara, Z. Cheng, A. R. Peters, D. R. Abayasekara, and D. C. Wathes. 2002. Effects of dietary polyunsaturated fatty acids on ovarian and uterine function in lactating dairy cows. Reproduction 124:119-131.

Rooke, J. A., C. C. Shao, and B. K. Speake. 2001. Effects of feeding tuna oil on the lipid composition of pig spermatozoa and in vitro characteristics of semen. Reproduction 121:315-322. 
Roqueta-Rivera, M., T. L. Abbott, M. Sivaguru, R. A. Hess, and M. T. Nakamura. 2011. Deficiency in the omega-3 fatty acid pathway results in failure of acrosome biogenesis in mice. Biol. Reprod. 85:721-732.

Safarinejad, M. R., S. Y. Hosseini, F. Dadkhah, and M. A. Asgari. 2010. Relationship of omega-3 and omega-6 fatty acids with semen characteristics, and anti-oxidant status of seminal plasma: A comparison between fertile and infertile men. Clin. Nutr. 29:100-105.

Santos, J. E. P., T. R. Bilby, W. W. Thatcher, C. R. Staples, and F. T. Silvestre. 2008. Long chain fatty acids of diet as factors influencing reproduction in cattle. Reprod. Domest. Anim. 43(Suppl. 2):23-30.

Schauff, D. J., and J. H. Clark. 1992. Effects of feeding diets containing calcium salts of long-chain fatty acids to lactating dairy cows. J. Dairy Sci. 75:2990-3002.

Senger, P. L. 2003. Pathways to Pregnancy and Parturition. 2nd ed. Current Conceptions Inc., Pullman, WA.

Silvestre, F. T., T. S. M. Carvalho, P. C. Crawford, J. E. P. Santos, C. R. Staples, T. Jenkins, and W. W. Thatcher. 2011. Effects of differential supplementation of fatty acids during the peripartum and breeding periods of Holstein cows: II. Neutrophil fatty acids and function, and acute phase proteins. J. Dairy Sci. 94:2285-2301.

Simopoulos, A. P. 2002. The importance of the ratio of omega-6/ omega-3 essential fatty acids. Biomed. Pharmacother. 56:365-379.

Simopoulos, A. P. 2013. Dietary omega-3 fatty acid deficiency and high fructose intake in the development of metabolic syndrome, brain metabolic abnormalities, and non-alcoholic fatty liver disease. Nutrients 5:2901-2923.

Sinedino, L. D. P., P. M. Honda, L. R. L. Souza, A. L. Lock, M. P. Boland, C. R. Staples, W. W. Thatcher, and J. E. P. Santos. 2017. Effects of supplementation with docosahexaenoic acid on reproduction of dairy cows. Reproduction 153:707-723.

Soita, H. W., J. A. Meier, M. Yu. P. Fehr, D. A. Christensen, J. J. McKinnon, and A. F. Mustafa. 2003. Effects of flaxseed supplementation on milk production, milk fatty acid composition and nutrient utilization by lactating dairy cows. Arch. Tierernahr. $57: 107-116$.

Sordillo, L. M. 2016. Nutritional strategies to optimize dairy cattle immunity. J. Dairy Sci. 99:4967-4982.

Spain, J. N., C. E. Polan, and B. A. Watkins. 1995. Evaluating effects of fish meal on milk fat yield of dairy cows. J. Dairy Sci. 78:1142-1153.

Stocco, D. M., and B. J. Clark. 1996. Role of steroidogenic acute regulatory protein (StAR) in steroidogenesis. Biochem. Pharmacol. 51:197-205.

Stoffel, W., B. Holz, B. Jenke, E. Binczek, R. H. Günter, C. Kiss, I. Karakesisoglou, M. Thevis, A. A. Weber, S. Arnhold, and K. Addicks. 2008. $\Delta 6$-Desaturase (FADS2) deficiency unveils the role of $\omega 3-$ and $\omega 6$-polyunsaturated fatty acids. EMBO J. 27:2281-2292.

Storlien, L. H., A. B. Jenkins, D. J. Chisholm, W. S. Pascoe, S. Khouri, and E. W. Kraegen. 1991. Influence of dietary fat composition on development of insulin resistance in rats. Relationship to muscle triglyceride and omega-3 fatty acids in muscle phospholipid. Diabetes 40:280-289.

Suksombat, W., L. P. Thanh, C. Meeprom, and R. Mirattanaphrai. 2016. Effect of linseed oil supplementation on performance and milk fatty acid composition in dairy cows. Anim. Sci. J. 87:15451553.

Thangavelu, G., M. G. Colazo, D. J. Ambrose, M. Oba, E. K. Okine, and M. K. Dyck. 2007. Diets enriched in unsaturated fatty acids enhance early embryonic development in lactating Holstein cows. Theriogenology 68:949-957.

Wang, X., L. P. Walsh, A. D. Reinhart, and D. M. Stocco. 2000. The role of arachidonic acid in steroidogenesis and steroidogenic acute regulatory (StAR) gene and protein expression. J. Biol. Chem. 275:20204-20209.

Wathes, D. C., D. R. E. Abayasekara, and R. J. Aitken. 2007. Polyunsaturated fatty acids in male and female reproduction. Biol. Reprod. 77:190-201. https://doi.org/10.1095/biolreprod.107.060558.

Weld, K. A., and L. E. Armentano. 2017. The effects of adding fat to diets of lactating dairy cows on total-tract neutral detergent fiber digestibility: A meta-analysis. J. Dairy Sci. 100:1766-1779.

Whitlock, L. A., D. J. Schingoethe, A. R. Hippen, K. F. Kalscheur, R. J. Baer, N. Ramaswamy, and K. M. Kasperson. 2002. Fish oil and extruded soybeans fed in combination increase conjugated linoleic acids in milk of dairy cows more than when fed separately. J. Dairy Sci. 85:234-243. https://doi.org/10.3168/jds.S0022-0302(02)74072 -1 .

Windschitl, P. M. 1991. Lactational performance of high producing dairy cows fed diets containing salmon meal and urea. J. Dairy Sci. 74:3475-3485.

Wonnacott, K. E., W. Y. Kwong, J. Hughes, A. M. Salter, R. G. Lea, P. C. Garnsworthy, and K. D. Sinclair. 2010. Dietary omega-3 and -6 polyunsaturated fatty acids affect the composition and development of sheep granulosa cells, oocytes and embryos. Reproduction 139:57-69. https://doi.org/10.1530/REP-09-0219.

Wu, Z., and J. T. Huber. 1994. Relationship between dietary fat supplementation and milk protein concentration in lactating cows: A review. Livest. Prod. Sci. 39:141-155.

Zachut, M., A. Arieli, H. Lehrer, L. Livshitz, S. Yakoby, and U. Moallem. 2010a. Effects of increased supplementation of n-3 fatty acids to transition dairy cows on performance and fatty acid profile in plasma, adipose tissue, and milk fat. J. Dairy Sci. 93:5877-5889.

Zachut, M., A. Arieli, and U. Moallem. 2011. Incorporation of dietary n-3 fatty acids into ovarian compartments in dairy cows and the effects on hormonal and behavioral patterns around estrus. Reproduction 141:833-840. https://doi.org/10.1530/REP-10-0518.

Zachut, M., I. Dekel, H. Lehrer, A. Arieli, A. Arav, L. Livshitz, S. Yakoby, and U. Moallem. 2010b. Effects of dietary fats differing in n-6:n-3 ratio fed to high-yielding dairy cows on fatty acid composition of ovarian compartments, follicular status, and oocyte quality. J. Dairy Sci. 93:529-545. https://doi.org/10.3168/jds.2009-2167.

Zeron, Y., A. Ocheretny, O. Kedar, A. Borochov, D. Sklan, and A. Arav. 2001. Seasonal changes in bovine fertility: Relation to developmental competence of oocytes, membrane properties and fatty acid composition of follicles. Reproduction 121:447-454.

Zeron, Y., D. Sklan, and A. Arav. 2002. Effect of polyunsaturated fatty acid supplementation on biophysical parameters and chilling sensitivity of ewe oocytes. Mol. Reprod. Dev. 61:271-278. 